\title{
Biological Role of Gellan Gum in Improving Scaffold Drug Delivery, Cell Adhesion Properties for Tissue Engineering Applications
}

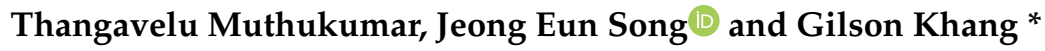 \\ Department of BIN Convergence Technology, Department of Polymer Nano Science \& Technology and Polymer \\ BIN Research Center, Chonbuk National University, Deokjin-gu, Jeonju 561-756, Korea; \\ auromuthu@gmail.com (T.M.); songje@jbnu.ac.kr (J.E.S.) \\ * Correspondence: gskhang@jbnu.ac.kr; Tel.: +82-63-270-2355; Fax: +82-63-270-2341
}

Academic Editor: Iva Pashkuleva

Received: 30 October 2019; Accepted: 6 December 2019; Published: 10 December 2019

\begin{abstract}
Over the past few decades, gellan gum (GG) has attracted substantial research interest in several fields including biomedical and clinical applications. The GG has highly versatile properties like easy bio-fabrication, tunable mechanical, cell adhesion, biocompatibility, biodegradability, drug delivery, and is easy to functionalize. These properties have put forth GG as a promising material in tissue engineering and regenerative medicine fields. Nevertheless, GG alone has poor mechanical strength, stability, and a high gelling temperature in physiological conditions. However, GG physiochemical properties can be enhanced by blending them with other polymers like chitosan, agar, sodium alginate, starch, cellulose, pullulan, polyvinyl chloride, xanthan gum, and other nanomaterials, like gold, silver, or composites. In this review article, we discuss the comprehensive overview and different strategies for the preparation of GG based biomaterial, hydrogels, and scaffolds for drug delivery, wound healing, antimicrobial activity, and cell adhesion. In addition, we have given special attention to tissue engineering applications of GG, which can be combined with another natural, synthetic polymers and nanoparticles, and other composites materials. Overall, this review article clearly presents a summary of the recent advances in research studies on GG for different biomedical applications.
\end{abstract}

Keywords: gellan gum; cell adhesion; tissue engineering; drug delivery; hydrogel; scaffold

\section{Introduction}

Gellan gum (GG) is a linear anionic high molecular weight exopolysaccharide, commercially produced by microbial fermentation of the Sphingomonas paucimobilis microorganism [1], comprised of tetrasaccharide (1,3- $\beta$-D-glucose (Glc), 1,4- $\beta$-D-glucuronic acid (GlcA), 1,4- $\beta$-D-glucose (Glc), and $1,4-\alpha$-L-rhamnose (Rha)) repeating units with one carboxyl side group [2]. Figure 1 shows that GG consist of repeating tetramers of L-rhamnose, D-glucuronic acid, and two D-glucose subunits. GG also contains glycated and acetate functionalities. Deacylated GG is the most commonly used in the tissue engineering (TE) and pharmaceutical fields [3], because of their relative ease of isolation and processing methodology. The GG average molecular weight is about $500 \mathrm{kDa}$ [4]. GG is commercially available under the trade name Gelrite ${ }^{\mathrm{TM}}$ (acyl GG or acylated GG) and Kelcogel ${ }^{\mathrm{TM}}$ (low acyl GG or deacylated GG) [5-8]. Other products related to GG can also be found under the trade name of Grovgel, nanogel-TC, Phytagel ${ }^{\circledR}$, and AppliedGel. 


\section{acylated gellan gum (AGG)}

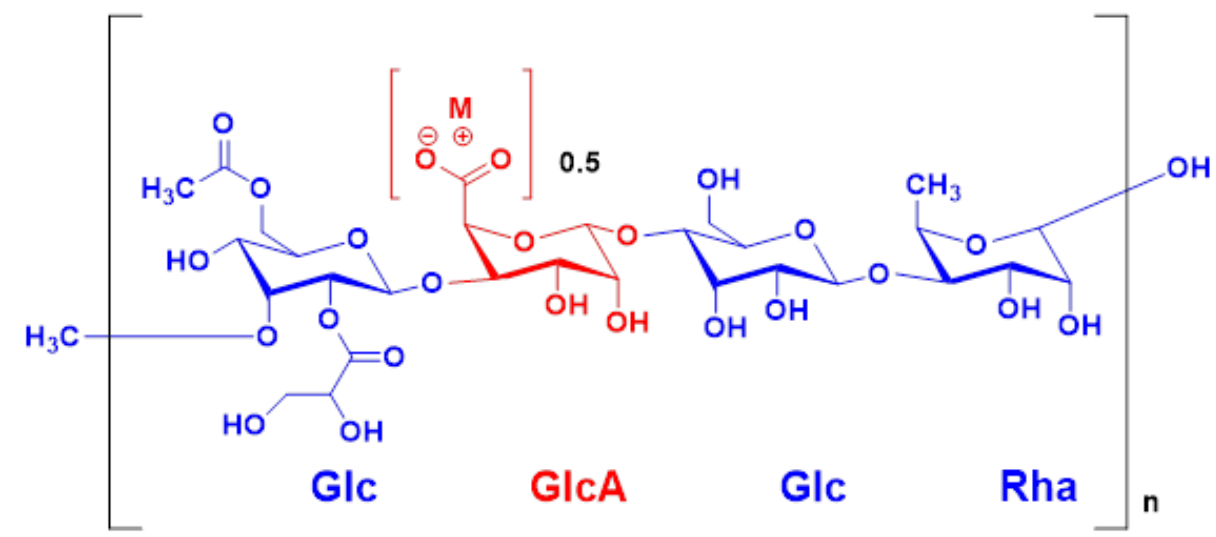

\section{deacylated gellan gum (dAGG)}

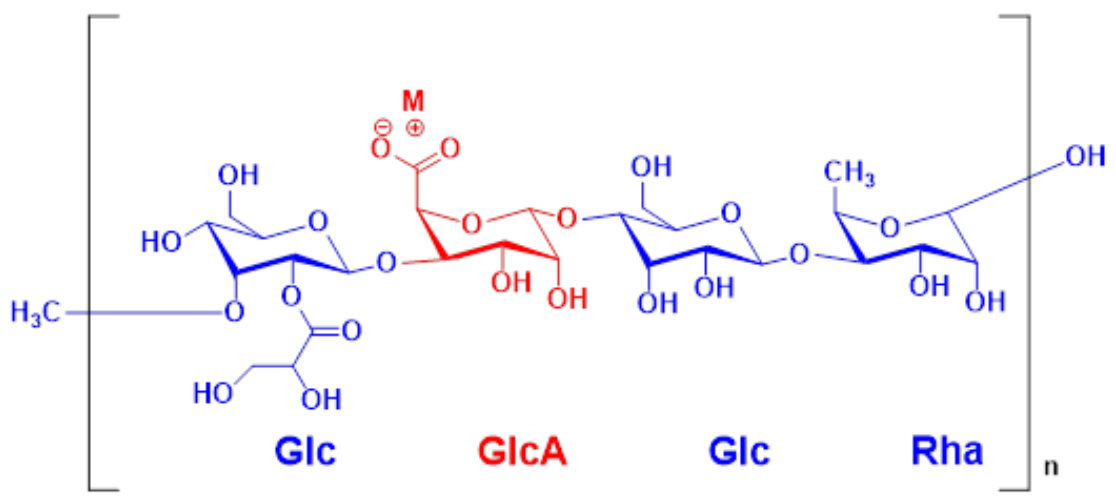

Figure 1. Showing the structure of acylated gellan gum (AGG) and deacylated gellan gum (dAGG).

GG is thermo-responsive [9], biocompatible [10-13], nontoxic [8,14,15], ductile $[8,16,17]$, and has the ability to tolerate heat and acid stress during the material fabrication process [18]. The GG composites produce elastic and soft gels, whereas pure GG produces a hard, transparent gel, with rigid and thermally stable products [19]. It has been reported that self-supporting hydrogels of GG can be formed by simple crosslinking with standard cell culturing media, with no added ions [20]. Chemical or covalent crosslinking using a chemical crosslinker, like 1-ethyl-3-(3-dimethylaminopropyl) arbodiimide (EDC), has also been reported for GG gelation [21]. GG gels form as a result of association between double-helical stretches that form ordered junction domains, interconnected by unordered chain segments [22].

The versatile properties of GG help in different TE and regenerative medicine (RM) applications [23]. The application of GG in cellular and acellular strategies has been successfully suggested for cartilage [24], drug delivery [25-27], and intervertebral disc repair [28-30]. The major attractive properties of GG that make them a suitable material for TE include its non-cytotoxicity, biocompatibility, structural similarities with native glycosaminoglycans, mild processing conditions, and mechanical properties similar to the elastic moduli of common tissue. The mechanical properties of the GG are improved by combining it with inorganic materials (for their flexibility), and biopolymers (with poor rigidity) became common and smart solutions to improve the mechanical properties of GG. Composites of GG have been recently accomplished by the introduction of hydroxyapatite (HAp) [31], bioactive glass [32,33], calcium phosphate (CaP) [34], hyaluronic acid (HA) [35], demineralized bone powder (DBP) [36], polyethylene glycol [37], silk fibrin [38], agar [39], saponin [40], and chondroitin sulfate [41]. 
Table 1 shows the different types of GG composites that are used for biological applications. GG is used in the pharmaceutical and biomedical fields, including for gene transfection, gene therapy, wound healing, cell adhesion, guided bone regeneration, dental care, ophthalmic formulations, biological signaling, and as protein carriers, biocides, and delivery agents [40-47]. GG is used in various drug formulations like controlled release, continuous release, injectable nanoparticles, gel beads, and in situ gels [48-51]. A new class of GG with improved mechanical properties are prepared using methacrylation procedures [52]. GG is an US food and drug administration (FDA) \& European union (EU) [53] approved biomaterial [45,54]. The mechanical properties of GG can be improved by modifying the type and the degree of crosslinks [52]. Cations can be used for cross linking GG [55], and covalent cross linking of GG gels improve its stability [56]. Commonly employed chemical cross linking, such as glycidyl methacrylation and methacrylic anhydride, can also be used to improve GG mechanical properties [56-58]. Modification of GG with tunable physical and mechanical properties have also been reported [52,59,60]. Physical and chemical crosslinking methods were studied for many natural materials, like hyaluronic acid (HA), alginate, gelatin, etc. [61-64]. The different strategies for preparing GG based materials are given in Figure 2.

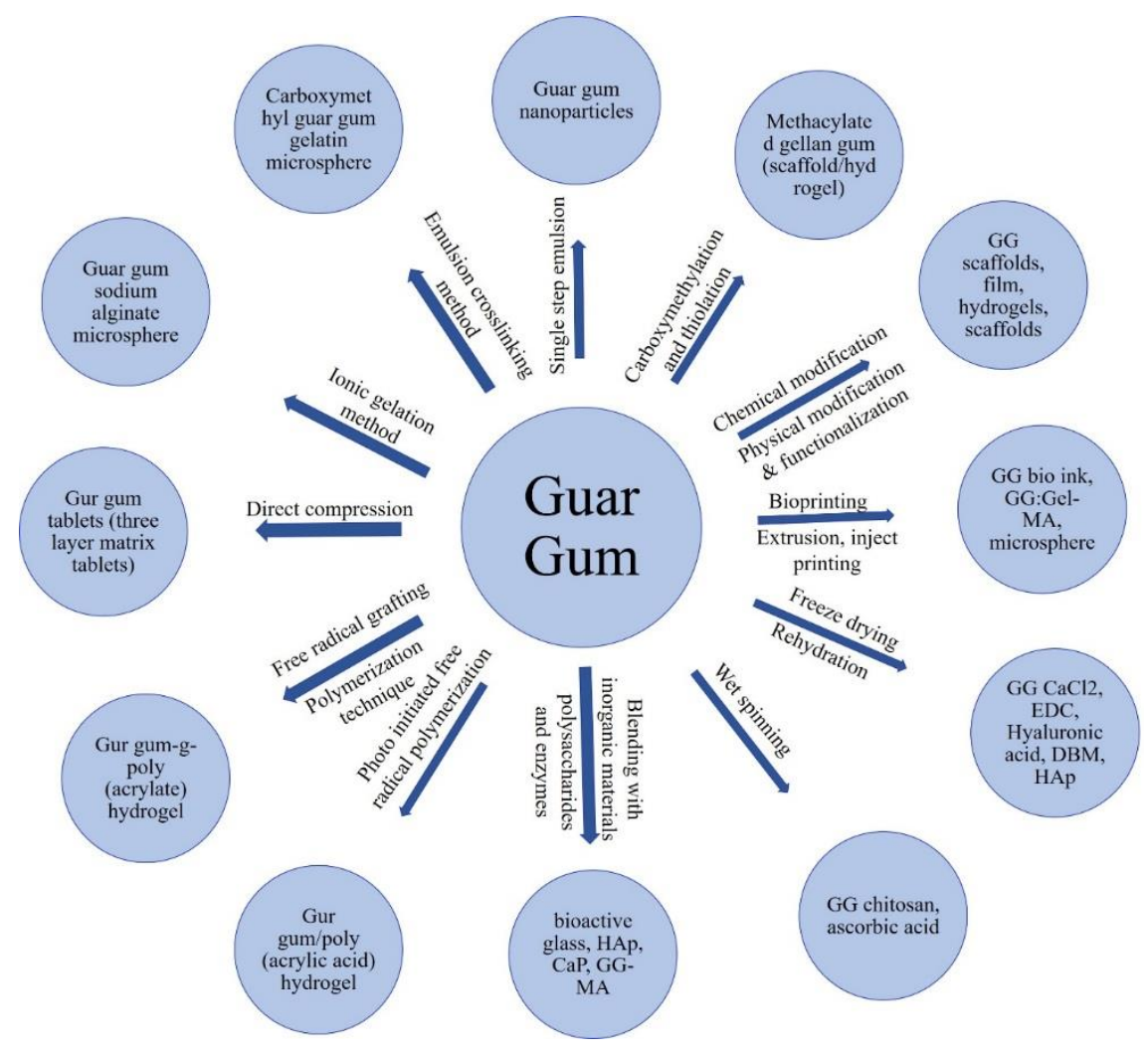

Figure 2. Major routes for preparing gellan gum-based biomaterials [4,32,34-39,65-69].

\section{Gellan Gum in Drug Delivery}

GG based nano-hydrogel systems for multiple drug delivery applications were recently studied by many researchers. For example, prednisolone and paclitaxel were chemically linked to GG, and their anti-inflammatory and anti-cancer effects were studied in malignant cells [70]. A multi-particulate drug delivery system with many small units $(0.05-2 \mathrm{~nm})$ provide numerous advantages over a single unite system due to their smaller size. They are less dependent on gastric emptying, have increased bioavailability, cause less local irritation, and reduce the risk of systemic toxicity. They also have better reproducible pharmacokinetic behavior than conventional formulations, and better disintegration, even though they have some drawbacks [71]. They are formed by subunits, such as micro/macrobeads, granules, particles, pellets, spheres, and spheroids. Whereas, drug-loaded GG is prepared by a simple 
process, by external ionotropic gelation methods using a dropwise addition of aqueous GG with dissolved/dispersed drugs into aqueous solution of cations [72]. Several drugs, mainly antibiotics, were encapsulated with floating GG beads to increase their retention time in the stomach [72,73]. GG has advantageous properties over other existing materials, like being capable of contact with cations present in physiological fluids, mucoadhesiveness, nontoxicity, resistance to temperature, its biodegradability, persistence in the presence of the acid environment and enzymes in the gastrointestinal tract (GIT), stability, and high water holding capacity, etc. Due to these properties, it can be easily formulated into different forms, like particles, film, hydrogels, fibers, in situ gelling systems, and many other forms, with sustained and controlled drug release [74].

Gold nanoparticles (AuNPs) with controlled release and stabilized with GG, were studied in mouse embryonic fibroblast cells and human glioma cell lines, LN-229 and NIH 3T3 [75]. AuNPS stabilized by GG and with doxorubicin hydrochloride (DOX) were also studied for their drug release and cytotoxic effects, in human glioma stem cell lines HNGC-2 and LN 229 [76]. Antibacterial activity using silver nanoparticles (AgNPs) stabilized with GG, and their cytotoxic activity in mouse embryonic fibroblast cells (NIH 3T3), were also evaluated [77]. GG coated Gold nanorods (AuNRs) have also been prepared and studied by researchers [78], for intercellular drug delivery and imaging. Recent studies have shown that GG can be used in ocular, gastric, and nasal drug delivery applications $[79,80]$. Hydrocolloid bead based GG was studied for slow drug release applications [81]. GG was also used for protein delivery systems, including implant for insulin delivery in diabetic rats. The blood glucose levels of the implanted diabetic rats were reduced to half of those of blanks, and the therapeutic effects were found to last for a week [82]. Jeong et al. [83] used hesperidin (heteropolysaccharide), which is widely used in tissue engineering applications, along with GG for cartilage regeneration, and confirmed the cartilage regeneration, cell adhesion, and differentiation ability of the prepared scaffold, using 3-(4,5-Dimethylthiazol-2-yl)-2,5-Diphenyltetrazolium Bromide (MTT), SEM, and RT-PCR studies. In another study, Levofloxacin hemihydrate was used as an in situ gelling ophthalmic solution along with GG [84], researchers studied the in vitro gelation time, drug release and stability, absorbed gelling time $(<15 \mathrm{~s})$, and prolonged in vitro drug release $(18-24 \mathrm{~h})$, with a stability of 6 months at $25{ }^{\circ} \mathrm{C} / 40{ }^{\circ} \mathrm{C}$. Vashisth et al. [85] used ofloxacin loaded GG/polyvinyl alcohol (PVA) nanofibers for gastroretentive/mucoadhesive drug delivery applications, and their results showed a biphasic drug release pattern with considerable mucoadhesion and gastric retention, in rat gastric mucosal membranes. In another study by Vashisth et al. [86], they evaluated the GG/PVA nanofiber scaffold for skin tissue regeneration applications. They were characterized by SEM, the infrared spectra (IR), differential scanning calorimetry (DSC), and X-ray diffraction (XRD) analysis. Their biocompatibility and cell adhesion studies were confirmed by culturing with human dermal fibroblast (3T3L1) cells. A recent study, using resveratrol loaded chitosan/GG nanofibers as a novel gastrointestinal delivery system [87], highlighted that the encapsulation efficacy of resveratrol was $86 \pm 6 \%$. Antioxidant activities of resveratrol loaded nanofiber material were significantly higher than controls, and based on these findings, the authors suggested that prepared GG/chitosan resveratrol loaded nanofibers hold great potential as a drug delivery carrier. A study by Mehnath et al. [88] used Sericin-chitosan doped maleate GG nanocomposites for the maximum reduction and cellular damage of mycobacteria in Mycobacterium tuberculosis (TB) infections, this paved the way for the development of macromolecules in the pulmonary delivery of TB drugs. A detailed application of GG in drug delivery applications has been extensively reported for several applications (Table 1), including oral drug delivery formulations based on GG, ophthalmic drug delivery formulations, nasal drug delivery formulations, and topical drug delivery formulations [74,89]. 
Table 1. Gellan gum (GG) composites used in the biological fields for various applications.

\begin{tabular}{|c|c|c|c|}
\hline S1 No & GG Composites & Applications & Reference \\
\hline 1 & Xanthan gum (XG) -HAp & Bone tissue engineering & [90] \\
\hline 2 & GG-XG-hyaluronan & Bone tissue engineering & [91] \\
\hline 3 & GG/Starch & Drug delivery system & [92] \\
\hline 4 & GG/alpha amylase & Pharmaceutical and biomedical & [5] \\
\hline 5 & GG/PVA-Ofloxacin & Gastroretentive/mucoadhesive drug delivery & [85] \\
\hline 6 & GG/kappa-carrageenan & Drugs on the ocular surface & [93] \\
\hline 7 & GG/Chitosan & $\begin{array}{l}\text { Nasal insert, antifungal agent, coatings, wound } \\
\text { healing, antibiotic }\end{array}$ & $\begin{array}{c}{[47,94-96]} \\
{[14]}\end{array}$ \\
\hline 8 & GG/kappa-carrageenan/alginates & Antifungal and antimicrobial drugs & [97] \\
\hline 9 & GG/XG & Anti-adhesive & [98] \\
\hline 10 & GG/pectin & Drug delivery & [15] \\
\hline 11 & GG/agar & Biomedical applications & [99] \\
\hline 12 & GG methacrylate/gelatin methacrylamide & In scaffolds for load-bearing tissues & [91] \\
\hline 13 & GG/alginate & Sustained drug release & [16] \\
\hline 14 & GG/titanium dioxide nanoparticles & Wound healing & [100] \\
\hline 15 & GG/HAp & Bone, vasculature & $\begin{array}{c}{[31,101]} \\
{[102]}\end{array}$ \\
\hline 16 & GG/Gelatin/genipin & material & [103] \\
\hline 17 & GG/PLGA microsphere & Vertebra & [101] \\
\hline 18 & GG/Gold nanorods & Bone & [104] \\
\hline 19 & GG/Bioglass & Bone & {$[32,105]$} \\
\hline 20 & GG/Graphine oxide & Scaffold & [106] \\
\hline 21 & $\begin{array}{l}\text { GG/HAGG/LAGG blends } \\
\text { methacrylation/HA }\end{array}$ & Intervertebral discs & [106] \\
\hline 22 & $\begin{array}{l}\mathrm{GG} / / \text { methacrylation/GG } \\
\text { microsphere/gelatin }\end{array}$ & Load bearing tissue & [107] \\
\hline 23 & GG/methacrylation & Intervertebral discs, $\mathrm{TE}$, cartilage repair & {$[58,108,109]$} \\
\hline 24 & GG/Cinnamate & Wound healing & [110] \\
\hline 25 & GG/Methacrylated gelatin & Cartilage & [111] \\
\hline 26 & GG/HA & $\begin{array}{l}\text { Skin repair/vascularization/cartilage } \\
\text { regeneration }\end{array}$ & [102] [35] \\
\hline 27 & GG/Laponite beads & Drug release & [112] \\
\hline 28 & GG/ gum cordia & Drug delivery & [99] \\
\hline 29 & GG/apigenin & Drug release & [113] \\
\hline 30 & GG/avidin/boptinylated adhesive & Cell culture & [114] \\
\hline 31 & GG/HAp/Lactoferrin & Bone tissue engineering & {$[115,116]$} \\
\hline 32 & GG/AuNPs & Anti-cancer drug delivery & [75] \\
\hline 33 & GG/AuNPs/DOX & Anti-cancer drug delivery & [76] \\
\hline 34 & GG/AgNPs & Antibacterial, cytotoxic & [77] \\
\hline 35 & GG/AuNRs & Intercellular drug delivery and imaging & [78] \\
\hline 36 & GG/poloxamer 407/carbopol 934P) & Controlled delivery and antibacterial activity & [117] \\
\hline 37 & GG/Lactoferrin & Bone Tissue Engineering & [115] \\
\hline 38 & GG/insulin & Drug delivery & [82] \\
\hline 39 & GG/poly(vinyl) alcohol & Tissue Engineering & [118] \\
\hline 40 & GG/levofloxacin hemihydrate & Ophthalmic solution & [84] \\
\hline 41 & GG/Polyvinylpyrrolidone (PVP) & Sustained release & [119] \\
\hline
\end{tabular}


Table 1. Cont.

\begin{tabular}{|c|c|c|c|}
\hline S1 No & GG Composites & Applications & Reference \\
\hline 42 & $\begin{array}{l}\text { Gelatin-grafted-GG-hydrogel } \\
\text { microsphere }\end{array}$ & Cell encapsulation and delivery & [120] \\
\hline 43 & GG hydrogel & Cartilage Tissue Engineering & [23], [121] \\
\hline 43 & GG/fibrin/agarose & Cartilage regeneration & [122] \\
\hline 44 & Ionic crosslinked methacrylated GG/Silk & Meniscus tissue engineering & [123] \\
\hline 45 & GG/Polydopamine & Bone tissue engineering & [105] \\
\hline 46 & GG/Collagen I, Beta -TCP & Bone graft material & [124] \\
\hline 47 & GG-MA hydrogels & Intervertebral Disc & $\begin{array}{c}{[28,106]} \\
{[125]}\end{array}$ \\
\hline 48 & GG/RGD & Cell adhesion, proliferation & [120] \\
\hline 49 & $\begin{array}{l}\text { GG/ UV crosslinked gelatin-methacryloyl } \\
\text { (geMA) }\end{array}$ & Cartilage grafts bioprinting & {$[126,127]$} \\
\hline 50 & GG/acrylamide grafted & Sustained release & [128] \\
\hline 51 & GG/ dextran sulfates/ cellulose sulfate & Drug delivery & [129] \\
\hline 52 & GG/polyvinylalcoho & Beta-blocker & [130] \\
\hline 53 & GG/alginate & Antibiotic, Antinflammatory & {$[73,131]$} \\
\hline 54 & GG/polyvinylalcohol & Antibiotic & [132] \\
\hline 55 & $\begin{array}{l}\text { GG/hyaluronic acid } \\
\text { ester/polyvinylalcohol }\end{array}$ & Wound healing & [133] \\
\hline 56 & GG/chitosan/PEG & Wound healing & [134] \\
\hline 57 & GG/glucosamine & Oral cancer treatment & [135] \\
\hline 58 & GG/HA & Cartilage regeneration & [35] \\
\hline 59 & GG/ poloxamer-heparin & Bone marrow stem cells delivery & [65] \\
\hline 60 & GG/PEG & Retinal pigment epithelial cells regeneration & [37] \\
\hline 61 & GG/ demineralized bone powder & Bone tissue regeneration & [36] \\
\hline 62 & GG/Agar & Cartilage regeneration & [39] \\
\hline 63 & GG/Silk fibroin & Chondrogenic differentiation & [38] \\
\hline 64 & GG/Saponin & Cartilage regeneration & [40] \\
\hline 65 & GG/Chondroitin sulfate & Cartilage regeneration & [41] \\
\hline 66 & GG/ Gelatin & Cartilage regeneration & [136] \\
\hline 67 & GG/Hesperidin & Cartilage regeneration & {$[83]$} \\
\hline 68 & GG/ duck feet derived collagen & Tissue Engineering & [137] \\
\hline 69 & GG hydrogel & Intervertebral disc & [106] \\
\hline 70 & GG/ polyvinyl alcohol & Skin tissue regeneration & [86] \\
\hline 71 & GG/PVA/Water & Skin tissue regeneration & [138] \\
\hline 72 & GG/Chitosan/ resveratrol & Gastrointestinal delivery & [87] \\
\hline 73 & GG/apigenin & Oral drug delivery & [113] \\
\hline 74 & GG/Laponite Beads & Gastrointestinal drug release & [112] \\
\hline 75 & Maleate GG/Sericin-chitosan & Mycobacterium tuberculosis & [88] \\
\hline 76 & $\begin{array}{l}\text { GG/sodium alginate/low-methoxyl pectin } \\
\text { coated carboxymethyl pullulan-ZnO } \\
\text { nanocomposites encapsulating erlotinib }\end{array}$ & Lung cancer therapy & [139] \\
\hline 77 & GG/Triamcinolone acetonide & Topical Ocular Delivery & [140] \\
\hline 78 & GG/Sericin/rice bran albumin & Cancer drug delivery & [141] \\
\hline 79 & GG/natamycin bilosomes & Ocular pharmacotherapy & [142] \\
\hline 80 & GG/Methotrexate & Drug delivery & [143] \\
\hline 81 & GG/brinzolamide & Ocular delivery & [144] \\
\hline
\end{tabular}




\section{Gellan Gum Cell Adhesion Properties}

GG sponge-like hydrogels were reported to show optimal conditions for tissue engineering and regenerative medicine (TERM), due to their microstructure pore arrangement, mechanical stability, and high water content, which all together assist in cell adhesion and proliferation [32,67]. The GG cell adhesion properties are further improved by functionalizing them with bioactive peptide or protein conjugates. In the biomedical fields of TE and RM, cell adhesion and migration are vital to attain better results, those features are not demonstrated naturally by GG hydrogels. These features are improved by combining proteins and peptide sequences. GG microspheres were covalently functionalized with gelatin by Wang et al. [120], and partially denatured collagen derivatives through redox-mediated cross-linking, to enable anchorage-dependent cells (ADC) bindings. Human fetal osteoblasts and human dermal fibroblasts used in their study were successfully well adhered to the surface of the spheres. The good morphology, cell viability, and proliferation were observed in both cell lines. Silva et al. $[125,145]$ proposed another strategy to improve cell adhesion on GG hydrogels. They modified GG using Diels-Alder clicks chemistry with synthetic peptide (GRGDS) derived from fibronectin. There are different studies reported previously that show the influence of hydrogel microstructure, like hydrophilicity and charge [146], degree of porosity and pore architecture [147], and matrix stiffness [148] on cell adhesion. GG combined with arginine-glycine-aspartic acid (RGD) sequences were reported to enhance integrin-mediated cell attachment [120].

Kim et al. [35] prepared chondrocyte encapsulated GG-based HA blended hydrogel for cartilage regeneration, and they reported that the hydrogel enhanced cell adhesion, viability, proliferation, and gene expression in an in vitro and in an in vivo model. The microstructure and morphology of the hydrogels are provided in Figure 3. The cross-section images of normal cells and cells cultured on the hydrogels show the adhesion of cells on the surface. The pores are formed due to the ice crystal formation from freeze-drying steps, which were smaller when HA content was increased in the hydrogels. Compared with controls, of the other treated groups, the GG/HA 1:0.75 group showed a large amount of chondrocyte cells adhered on the surface which was supported by MTT assay results, and confocal fluorescent images performed at 7, 14 and 21 days (Figure 4)

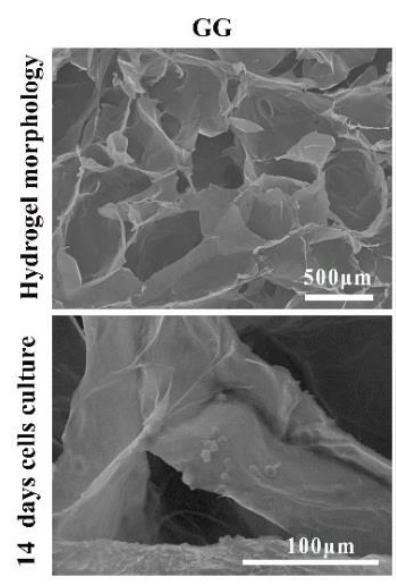

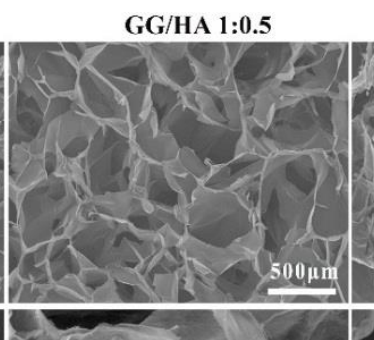

GG/HA 1:0.75
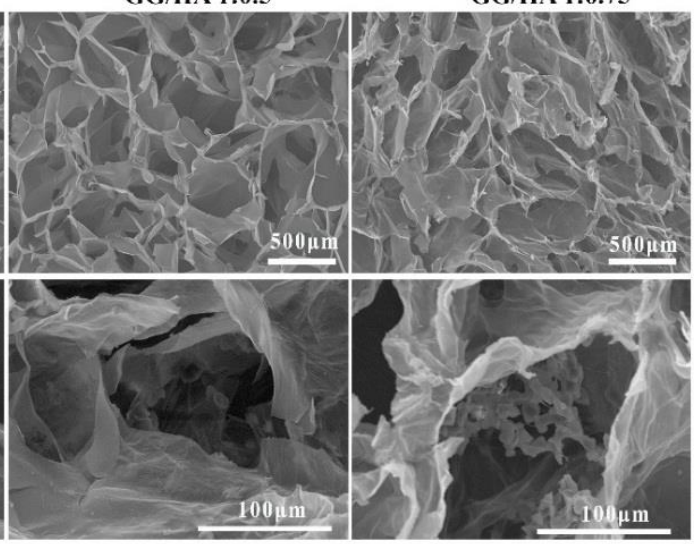

GG/HA 1:1

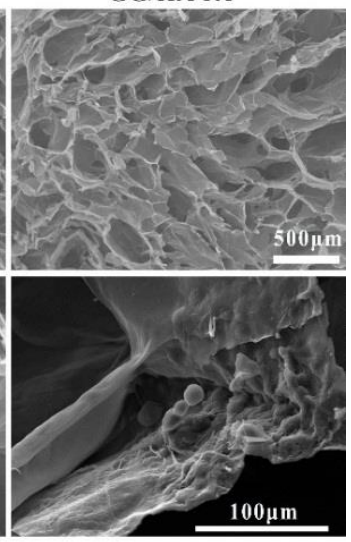

Figure 3. SEM observation of hydrogel morphology, and 14 days of culturing chondrocyte cells on the scaffold surface [35]. 

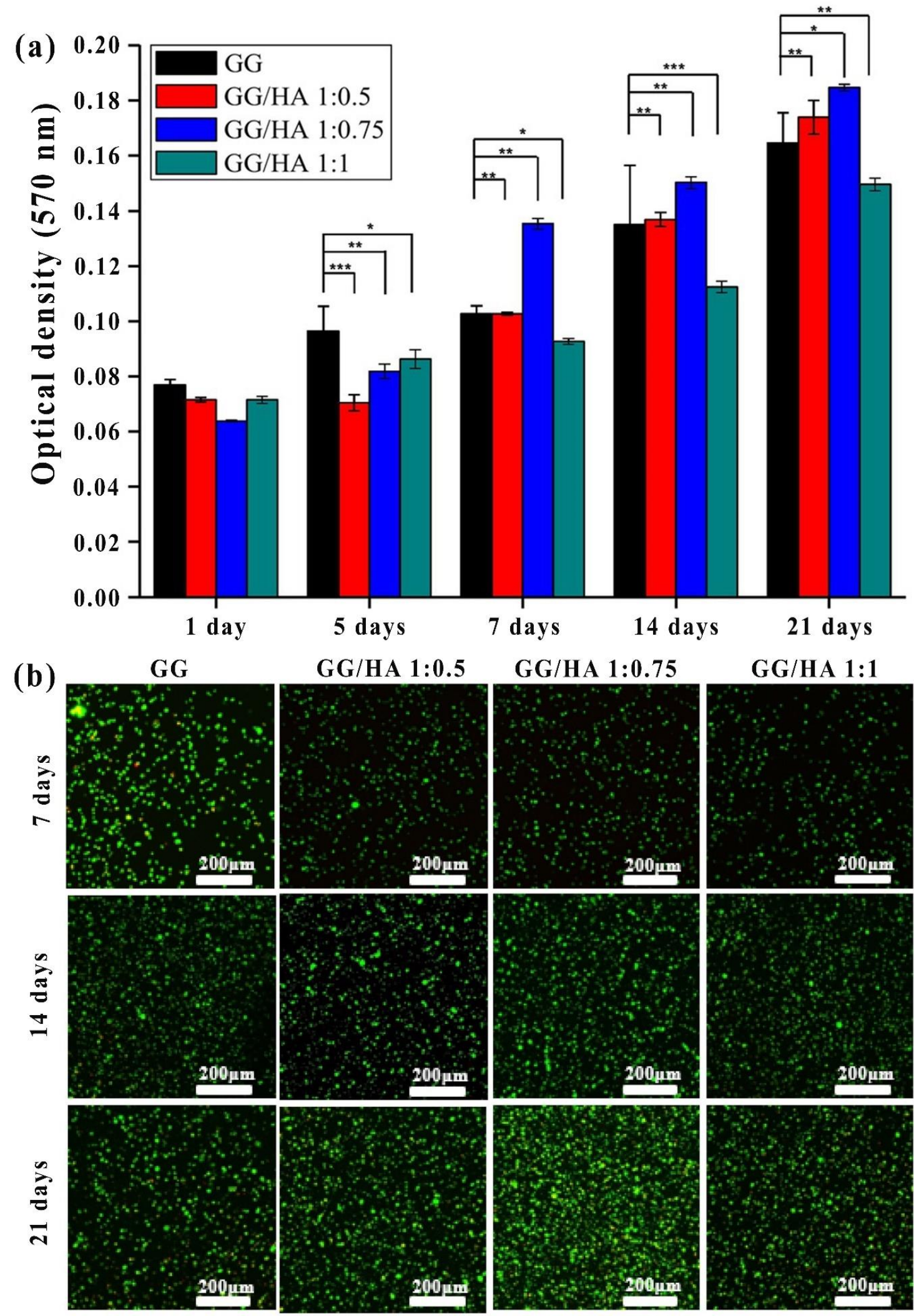

Figure 4. MTT assay (a) (values are mean $\pm \mathrm{SD}, \mathrm{n}=3, p<0.05\left(^{*}\right), p<0.01\left(^{* *}\right)$, and $p<0.001\left(^{* * *}\right)$ ), and live (green) and dead (red) images of cells encapsulated in hydrogel analyzed in z-stack mode (b) (scale bar $=100 \mu \mathrm{m})$ [35]. 
They studied the gene expression of collagen I and II in an in vitro model. In another study, GG/poloxamer-heparin (PoH) hydrogel was used as a carrier for bone marrow stem cell (BMSCs) delivery, in that experiment, they prepared a double network of GG hydrogel composed of PoH as a matrix platform for stem cell cultivation. They found that the hydrogel supported cell adhesion, distribution (Figure 5), and ECM production in an in vivo model [65]. Shin et al. [38] used GG/Silk fibroin (SF) for the chondrogenic differentiation ability of BMSCs, using miR-30.

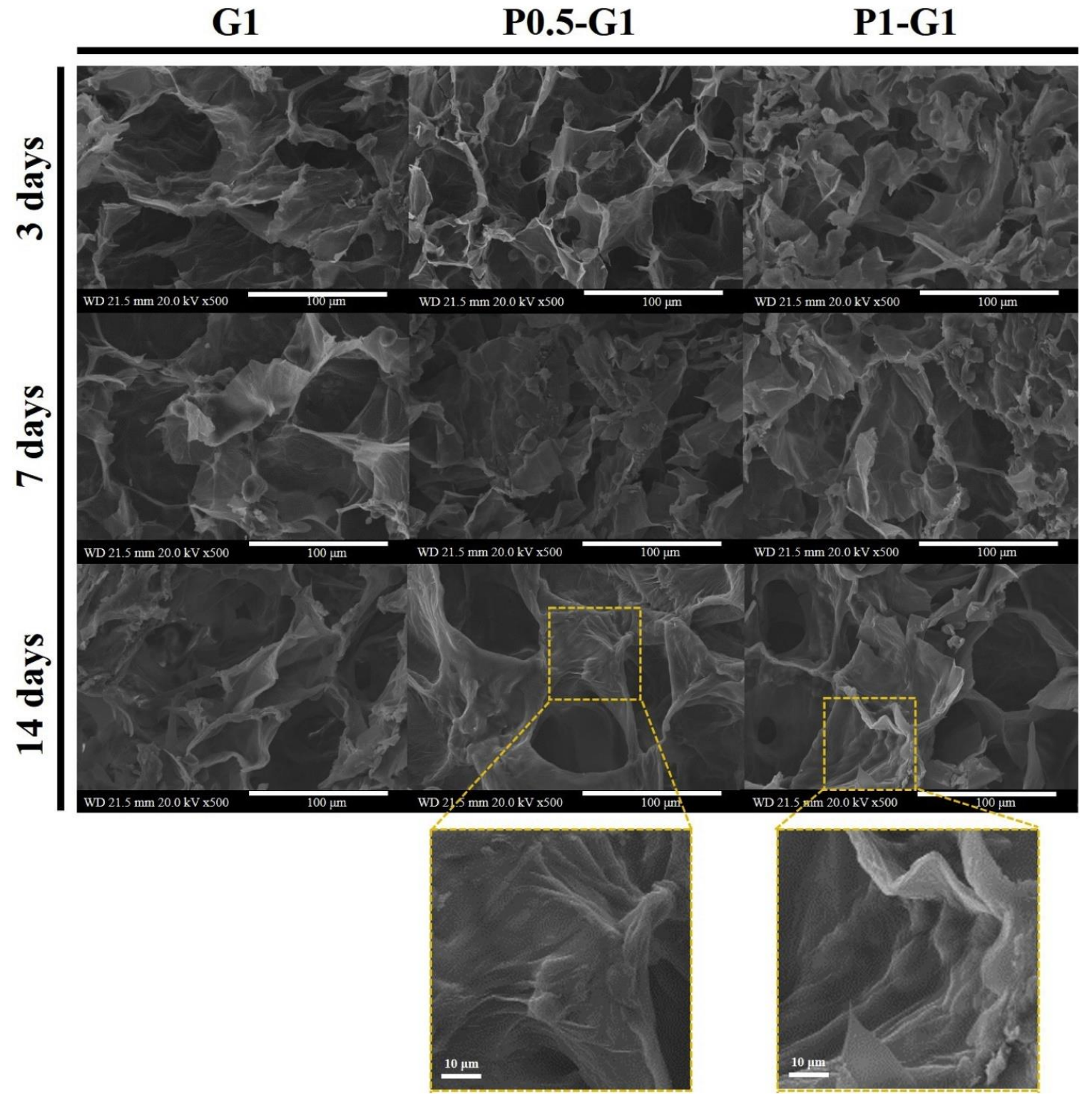

Figure 5. Scanning electron microscopic (SEM) images showing the cell adhesion and distribution on the surface of prepared hydrogels at 3, 7 and 14 days of culturing. G-gellan gum, P-poloxamer-heparin. The magnified images show the cells adhered to the hydrogel [65].

Kim et al. [37] used GG/PEG hydrogel for engineering retinal pigment epithelial cells (RPECs) for transplantation. They prepared PEG/GG with different $w \mathrm{t} \%$, and RPECs were cultured on their surface to confirm their cell adhesion and growth properties. They observed biocompatibility (>90\%) in the prepared hydrogels that were confirmed by confocal, scanning electron microscopy (SEM) and RT-PCR (Figure 6). 

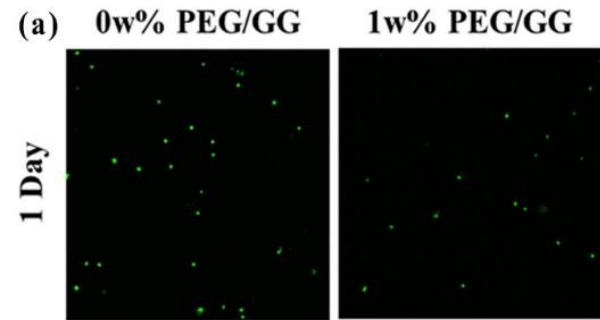

3w\% PEG/GG

5w\% PEG/GG
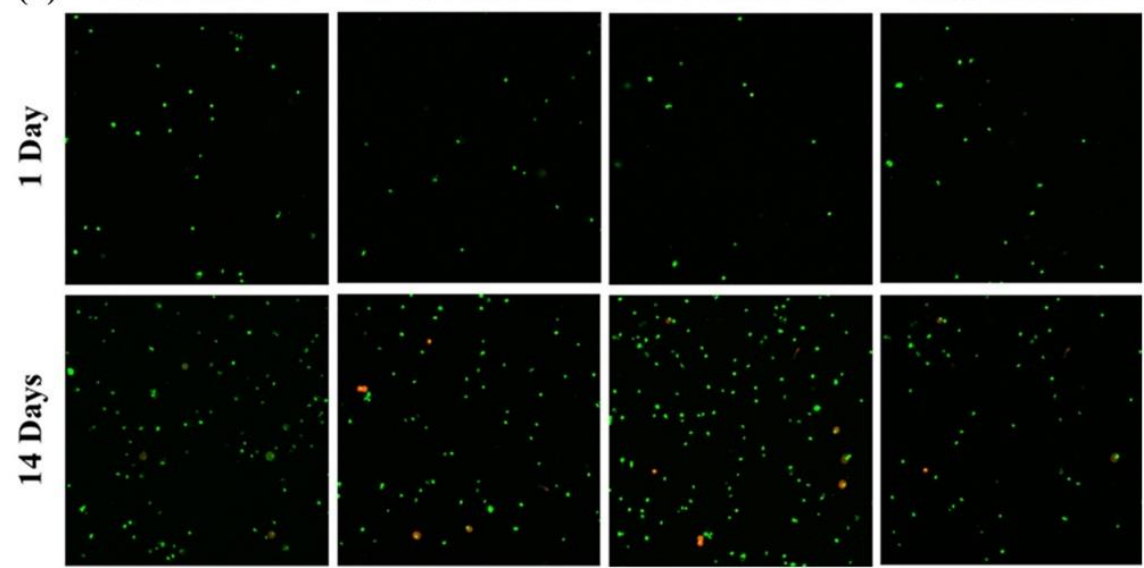

(b) $0 \mathrm{w} \%$ PEG/GG

1w\% PEG/GG
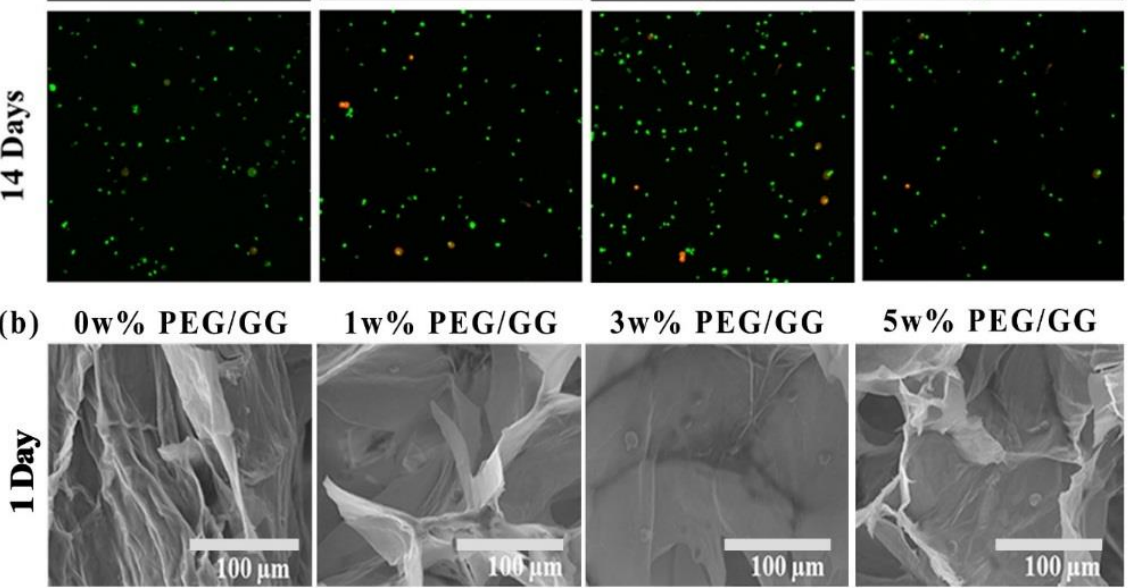

3 W\% PEG/GG

5 W\% PEG/GG
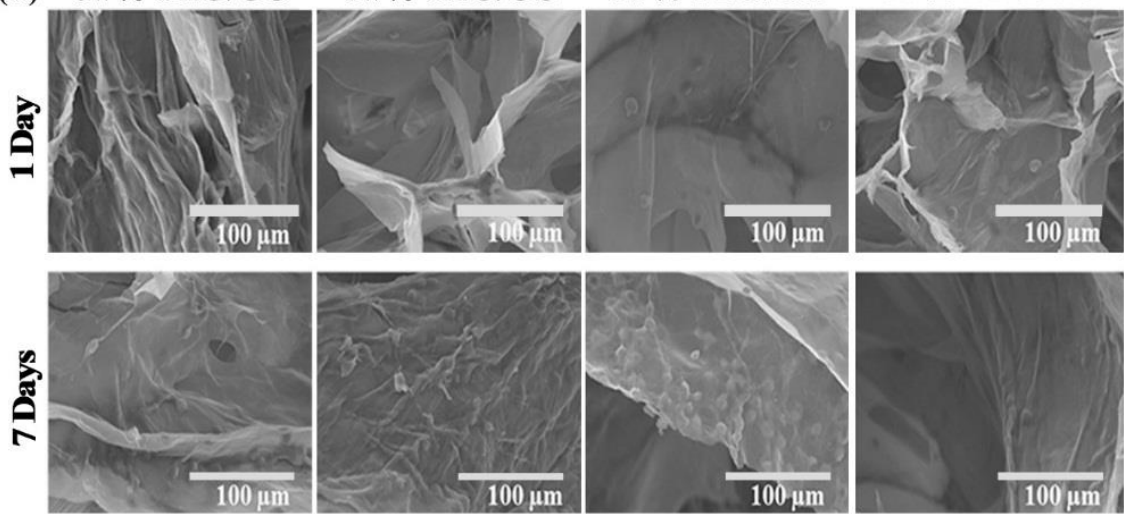

Figure 6. (a) Viability of human Retinal pigment epithelium (ARPE) live and dead cell staining images using a confocal Z-stack $(100 \mu \mathrm{m})$, on PEG/GG hydrogels on days 1 and 14 . Live and dead cells were stained in green and red, respectively. (b) SEM images showing the cell adhesion and proliferation on the surface of the hydrogels (PEG/GG) on days 1 and 7 [37].

Confocal images showed significantly higher cell numbers at 14 days in the $3 \mathrm{w} \%$ PEG/GG hydrogel group, compared with other groups studied, including control groups. This was further confirmed by SEM images taken on days 1 and 7 of RPECs cultured on the surface of the hydrogel. The Proliferation of RPE cells was further confirmed by MTT, and gene expression studies using RT-PCR (Figure 7). The gene expression was normalized by $\beta$-actin, the gene expressions of RPE 65 (isomerase enzyme in RPE cells that catalyze a crucial step in the visual (retinoid) cycle), CRALBP (36-kDa water-soluble protein found in the retina and pineal gland that binds 11-cis retinol), and NPRA (which regulates the gene expression associated with RPE cell proliferation and sub-retinal fluid absorption) [149-151] were reported to be higher in the $3 \mathrm{w} \%$ hydrogel in all groups on all days, compared with other treated and control groups. 

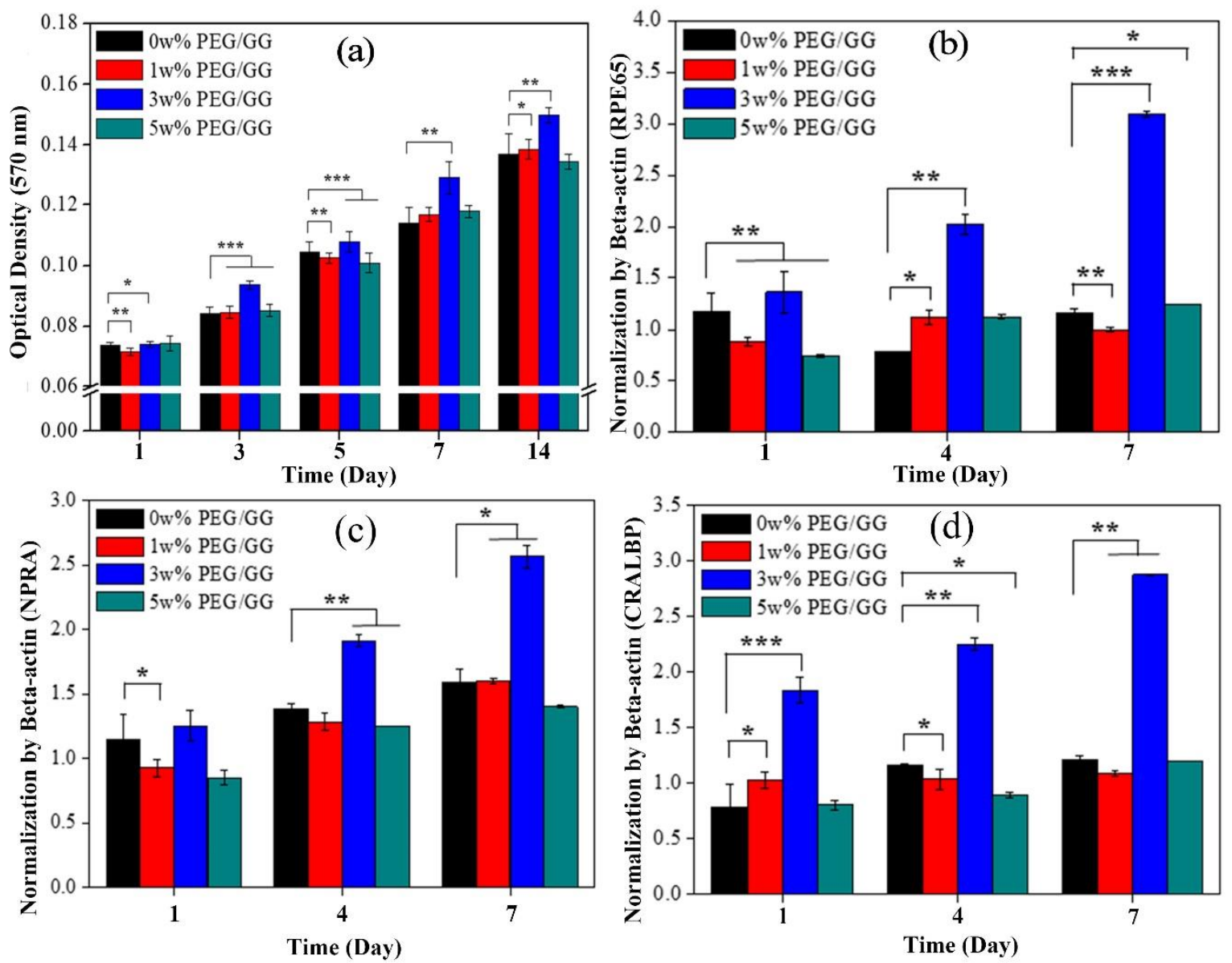

Figure 7. (a) Proliferation of ARPE at days 1, 3, 5, 7 and 14, studied by MTT assay ( $\mathrm{n}=3$ in each group, $p^{*}<0.5, p^{* *}<0.05$, and $p^{* * *}<0.01$ ). Gene expression of ARPE on PEG/GG hydrogels was analyzed by RT-PCR after 1, 4 and 7 days. (b) Quantitative analysis of retinal pigment epithelial 65 (RPE65) expression (c), Quantitative analysis of NPRA (d), Quantitative analysis of CRALBP normalized to Beta-actin $\left(p^{*}<0.5, p^{* *}<0.05\right.$, and $\left.p^{* * *}<0.001\right)$ [37].

In another study, Kim et al. [36] studied the application of a GG/demineralized bone powder (DBP) scaffold for bone tissue engineering applications in an in vitro and an in vivo model. Initial characterization was performed for the attachment and proliferation of BMSCs, after confirming their viability and their rate of proliferation, they were studied in an in vivo rat model and it was confirmed that the 1\% GG/DBP showed better osteogenic effects, using micro CT analysis (Figure 8) and histology data. The quantitative evaluation of bone formation was measured using micro-CT, the results showed bone mineral density (BMD), bone surface (BS), bone volume (BV), Total volume (TV), BV/TV (Bone Volume over Total Volume), trabecular number (Tb.N), and trabecular separation (Tb.Sp), respectively. These factors play an important role in measuring bone regeneration and bone strength. The bone mineral density was reported to be significantly increased in treated groups, over a period of 4 weeks. Their findings clearly confirmed that the $1 \%$ GG/DBP scaffold significantly increased bone density in treated groups, compared with control and other groups. 

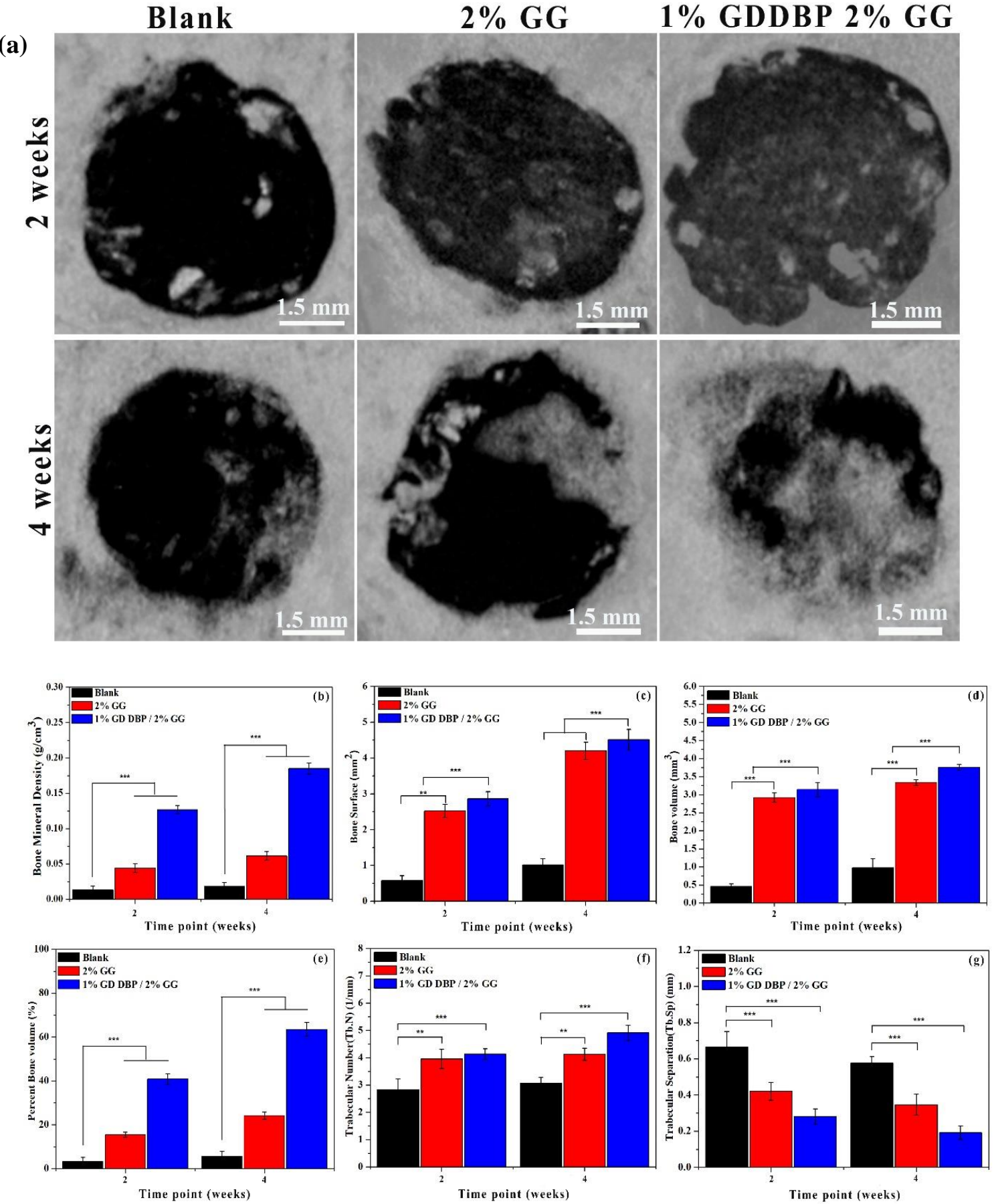

Figure 8. (a) Micro-CT images after in vivo implanted for 2 and 4 weeks, samples of blank, and 2\% GG and $1 \%$ Gallus gallus var domesticus (GD) demineralized bone powder (DBP) 2\% GG samples. (b) Bone mineral density (BMD), (c) Bone surface (BS), (d) Bone volume (BV), (e) Percent bone volume (PBV), (f) Trabecular number (Tb.N), and (g) Trabecular separation (Tb.Sp) $\left(p^{*}<0.05, p^{* *}<0.01, p^{* * *}<0.001\right)$ [36].

A recent study by Baek et al. [39] using GG/Agar, reported that the material demonstrated adhesion and proliferation of chondrocytes increased with the addition of agar. All the hydrogels were prepared using GG/Agar showed good cell adhesion and proliferation of rabbit chondrocytes. They also reported that the increasing agar concentration increased the pore size of the hydrogel and helped increase cell adhesion. The SEM image clearly represents cells seeded on the scaffolds present in a more spindle fibroblast-like shape, indicating an enhanced cell spreading with the synthesis of extracellular matrix. An increased amount of cell adhesion and proliferation were observed on the 
scaffold on days 7 and 14 (Figure 9). They also reported that the morphology of the material showed a suitable porous microstructure (between 70 and $180 \mu \mathrm{m}$ ), which allows for ideal water uptake for both increased mechanical properties, and optimal nutrient and oxygen diffusion for cells during growth.
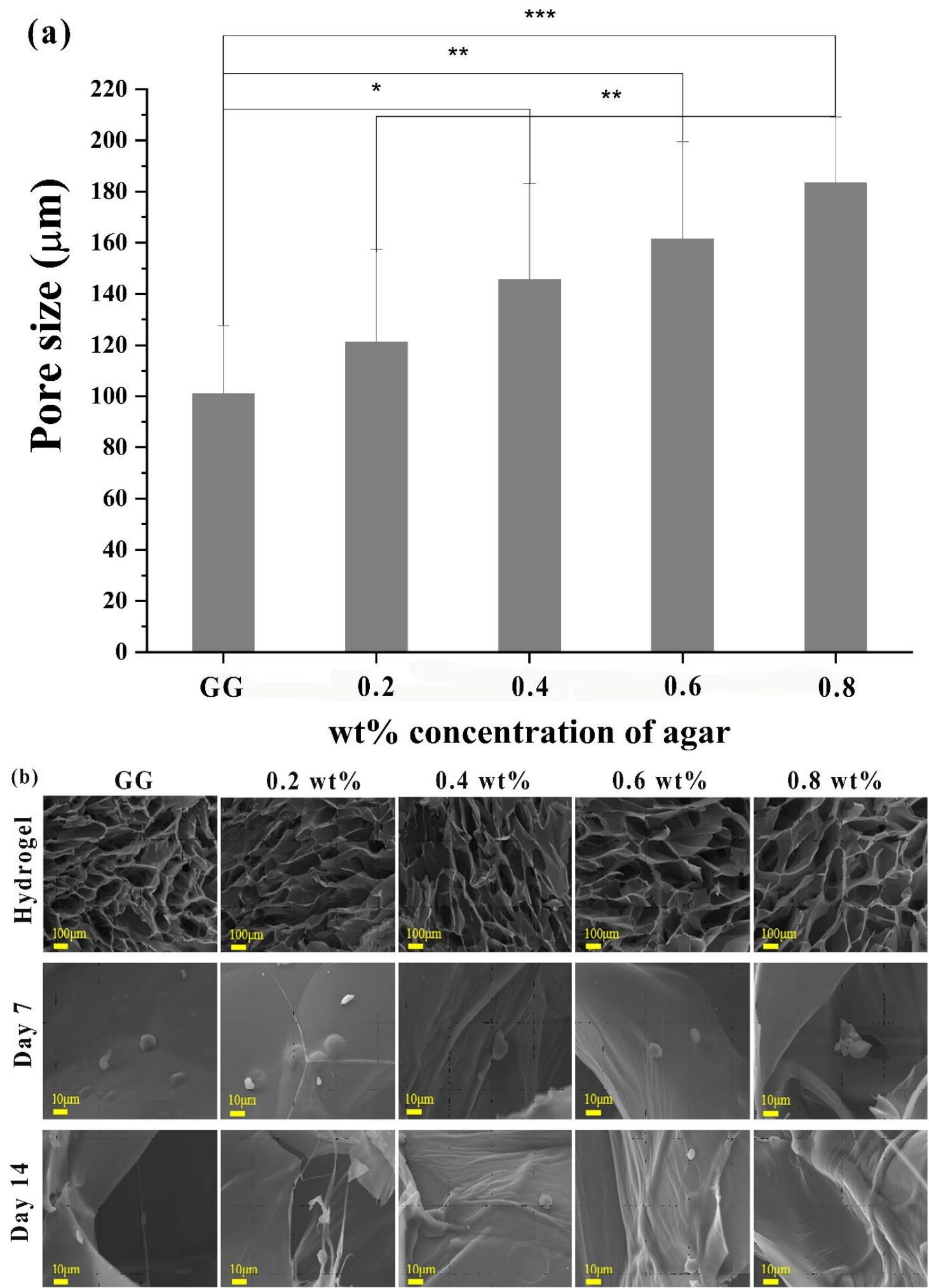

Figure 9. (a) Pore size of the hydrogels with different agar wt $\%\left(p^{*}<0.05, p^{* *}<0.01\right.$, and $\left.p^{* * *}<0.001\right)$. (b) SEM images of pristine hydrogel and chondrocytes morphology in GG and GG/Agar hydrogel, cultured for 7 and 14 days [39]. 


\section{Conclusion}

This review informs readers about the applications of GG, particularly its emerging potential as a biomaterial for tissue engineering, drug delivery, cartilage regeneration, pharmaceutical, and ocular applications. However, the properties and extensive capacities of GG, such as biocompatibility, biodegradability, rapid gelation, water holding capacity, and non-toxicity, provides more opportunities for modifying, optimizing, and preparing many composites as biocompatible, hydrogels, scaffolds, porous material, drug delivery vehicles, cell carriers, and as active material in the pharmaceutical field, etc. As part of this review, we have collected and presented important research being carried out using GG alone, and in combination with other materials. The studies carried out with GG composites for several applications listed here are smaller, due to its diverse properties. The research being carried out by several researchers will surely bring many more advanced products, which will be beneficial for human beings in the future.

Funding: This research was supported by a grant from the Korea Health Technology Research and Development Project, through the Korea Health Industry Development Institute (KHIDI), funded by the Ministry of Health and Welfare, Republic of Korea (grant number: HI15C2996).

Conflicts of Interest: The authors declare no conflict of interest. The funders had no role in the design of the study, analyses, or interpretation of data; in the writing of the manuscript, or in the decision to publish the results.

\section{References}

1. Maji, K.; Dasgupta, S.; Pramanik, K.; Bissoyi, A. Preparation and Evaluation of Gelatin-Chitosan-Nanobioglass 3D Porous Scaffold for Bone Tissue Engineering. Int. J. Biomater. 2016, 2016, 14. [CrossRef] [PubMed]

2. Jansson, P.-E.; Lindberg, B.; Sandford, P.A. Structural studies of gellan gum, an extracellular polysaccharide elaborated by Pseudomonas elodea. Carbohydr. Res. 1983, 124, 135-139. [CrossRef]

3. Osmalek, T.; Froelich, A.; Tasarek, S. Application of gellan gum in pharmacy and medicine. Int. J. Pharm. 2014, 466, 328-340. [CrossRef] [PubMed]

4. Bacelar, A.H.; Silva-Correia, J.; Oliveira, J.M.; Reis, R.L. Recent progress in gellan gum hydrogels provided by functionalization strategies. J. Mater. Chem. B 2016, 4, 6164-6174. [CrossRef]

5. Chakraborty, S.; Jana, S.; Gandhi, A.; Sen, K.K.; Zhiang, W.; Kokare, C. Gellan gum microspheres containing a novel alpha-amylase from marine Nocardiopsis sp. strain B2 for immobilization. Int. J. Biol. Macromol. 2014, 70, 292-299. [CrossRef]

6. Mahdi, M.H.; Conway, B.R.; Smith, A.M. Development of mucoadhesive sprayable gellan gum fluid gels. Int. J. Pharm. 2015, 488, 12-19. [CrossRef]

7. Rosas-Flores, W.; Ramos-Ramirez, E.G.; Salazar-Montoya, J.A. Microencapsulation of Lactobacillus helveticus and Lactobacillus delbrueckii using alginate and gellan gum. Carbohydr. Polym. 2013, 98, 1011-1017. [CrossRef]

8. Salunke, S.R.; Patil, S.B. Ion activated in situ gel of gellan gum containing salbutamol sulphate for nasal administration. Int. J. Biol. Macromol. 2016, 87, 41-47. [CrossRef]

9. Warren, H.; in het Panhuis, M. Highly conducting composite hydrogels from gellan gum, PEDOT:PSS and carbon nanofibres. Synth. Met. 2015, 206, 61-65. [CrossRef]

10. Wang, F.; Wen, Y.; Bai, T. The composite hydrogels of polyvinyl alcohol-gellan gum-Ca( $\left.{ }^{2+}\right)$ with improved network structure and mechanical property. Mat. Sci. Eng. C Mater. 2016, 69, 268-275. [CrossRef]

11. Kang, D.; Zhang, H.-B.; Nitta, Y.; Fang, Y.-P.; Nishinari, K. Gellan. In Polysaccharides: Bioactivity and Biotechnology; Ramawat, K.G., Mérillon, J.-M., Eds.; Springer International Publishing: Cham, Switzerland, 2015; pp. 1627-1682.

12. Karthika, J.S.; Vishalakshi, B. Novel stimuli responsive gellan gum-graft-poly(DMAEMA) hydrogel as adsorbent for anionic dye. Int. J. Biol. Macromol. 2015, 81, 648-655. [CrossRef] [PubMed]

13. Pacelli, S.; Paolicelli, P.; Dreesen, I.; Kobayashi, S.; Vitalone, A.; Casadei, M.A. Injectable and photocross-linkable gels based on gellan gum methacrylate: A new tool for biomedical application. Int. J. Biol. Macromol. 2015, 72, 1335-1342. [CrossRef] [PubMed] 
14. Sonje, A.G.; Mahajan, H.S. Nasal inserts containing ondansetron hydrochloride based on Chitosan-gellan gum polyelectrolyte complex: In vitro-in vivo studies. Mat. Sci. Eng. C 2016, 64, 329-335. [CrossRef] [PubMed]

15. Prezotti, F.G.; Cury, B.S.; Evangelista, R.C. Mucoadhesive beads of gellan gum/pectin intended to controlled delivery of drugs. Carbohydr. Polym. 2014, 113, 286-295. [CrossRef] [PubMed]

16. Jana, S.; Das, A.; Nayak, A.K.; Sen, K.K.; Basu, S.K. Aceclofenac-loaded unsaturated esterified alginate/gellan gum microspheres: In vitro and in vivo assessment. Int. J. Biol. Macromol. 2013, 57, 129-137. [CrossRef]

17. Goyal, R.; Tripathi, S.K.; Tyagi, S.; Ravi Ram, K.; Ansari, K.M.; Shukla, Y.; Kar Chowdhuri, D.; Kumar, P.; Gupta, K.C. Gellan gum blended PEI nanocomposites as gene delivery agents: Evidences from in vitro and in vivo studies. Eur. J. Pharm. Biopharem. 2011, 79, 3-14. [CrossRef]

18. Morris, E.R.; Nishinari, K.; Rinaudo, M. Gelation of gellan-A review. Food Hydrocoll. 2012, $28,373-411$. [CrossRef]

19. Grasdalen, H.; Smidsrød, O. Gelation of gellan gum. Carbohydr. Polym. 1987, 7, 371-393. [CrossRef]

20. Smith, A.M.; Shelton, R.M.; Perrie, Y.; Harris, J.J. An initial evaluation of gellan gum as a material for tissue engineering applications. J. Biomater. Appl. 2007, 22, 241-254. [CrossRef]

21. Dentini, M.; Desideri, P.; Crescenzi, V.; Yuguchi, Y.; Urakawa, H.; Kajiwara, K. Synthesis and Physicochemical Characterization of Gellan Gels. Macromolecules 2001, 34, 1449-1453. [CrossRef]

22. Yuguchi, Y.; Urakawa, H.; Kitamura, S.; Wataoka, I.; Kajiwara, K. The sol-gel transition of gellan gum aqueous solutions in the presence of various metal salts. In Physical Chemistry and Industrial Application of Gellan Gum; Nishinari, K., Ed.; Springer: Berlin/Heidelberg, Germany, 1999; pp. 41-47.

23. Oliveira, J.T.; Martins, L.; Picciochi, R.; Malafaya, P.B.; Sousa, R.A.; Neves, N.M.; Mano, J.F.; Reis, R.L. Gellan gum: A new biomaterial for cartilage tissue engineering applications. J. Biomed. Mater. Res. 2010, 93, 852-863. [CrossRef] [PubMed]

24. Oliveira, J.T.; Gardel, L.S.; Rada, T.; Martins, L.; Gomes, M.E.; Reis, R.L. Injectable gellan gum hydrogels with autologous cells for the treatment of rabbit articular cartilage defects. J. Ortho. Res. 2010, 28, 1193-1199. [CrossRef] [PubMed]

25. Matricardi, P.; Cencetti, C.; Ria, R.; Alhaique, F.; Coviello, T. Preparation and characterization of novel gellan gum hydrogels suitable for modified drug release. Molecules 2009, 14, 3376-3391. [CrossRef] [PubMed]

26. Babu, R.J.; Sathigari, S.; Kumar, M.T.; Pandit, J.K. Formulation of controlled release gellan gum macro beads of amoxicillin. Curr. Drug Deliv. 2010, 7, 36-43. [CrossRef] [PubMed]

27. Miyazaki, S.; Aoyama, H.; Kawasaki, N.; Kubo, W.; Attwood, D. In situ-gelling gellan formulations as vehicles for oral drug delivery. J. Controlled Release 1999, 60, 287-295. [CrossRef]

28. Pereira, D.R.; Silva-Correia, J.; Caridade, S.G.; Oliveira, J.T.; Sousa, R.A.; Salgado, A.J.; Oliveira, J.M.; Mano, J.F.; Sousa, N.; Reis, R.L. Development of gellan gum-based microparticles/hydrogel matrices for application in the intervertebral disc regeneration. Tissue Eng. Part. C Methods 2011, 17, 961-972. [CrossRef]

29. van Uden, S.; Silva-Correia, J.; Oliveira, J.M.; Reis, R.L. Current strategies for treatment of intervertebral disc degeneration: Substitution and regeneration possibilities. Biomater. Res. 2017, 21, 22. [CrossRef]

30. Pereira, D.R.; Silva-Correia, J.; Oliveira, J.M.; Reis, R.L.; Pandit, A.; Biggs, M.J. Nanocellulose reinforced gellan-gum hydrogels as potential biological substitutes for annulus fibrosus tissue regeneration. Nanomedicine 2018, 14, 897-908. [CrossRef]

31. Manda, M.G.; da Silva, L.P.; Cerqueira, M.T.; Pereira, D.R.; Oliveira, M.B.; Mano, J.F.; Marques, A.P.; Oliveira, J.M.; Correlo, V.M.; Reis, R.L. Gellan gum-hydroxyapatite composite spongy-like hydrogels for bone tissue engineering. J. Biomed. Mater. Res. 2018, 106, 479-490. [CrossRef]

32. Gantar, A.; da Silva, L.P.; Oliveira, J.M.; Marques, A.P.; Correlo, V.M.; Novak, S.; Reis, R.L. Nanoparticulate bioactive-glass-reinforced gellan-gum hydrogels for bone-tissue engineering. Mat. Sci. Eng. C-Mater. 2014, 43, 27-36. [CrossRef]

33. Douglas, T.E.; Piwowarczyk, W.; Pamula, E.; Liskova, J.; Schaubroeck, D.; Leeuwenburgh, S.C.; Brackman, G.; Balcaen, L.; Detsch, R.; Declercq, H.; et al. Injectable self-gelling composites for bone tissue engineering based on gellan gum hydrogel enriched with different bioglasses. Biomed. Mater. 2014, 9, 045014. [CrossRef] [PubMed] 
34. Douglas, T.E.L.; Krawczyk, G.; Pamula, E.; Declercq, H.A.; Schaubroeck, D.; Bucko, M.M.; Balcaen, L.; Van Der Voort, P.; Bliznuk, V.; van den Vreken, N.M.F.; et al. Generation of composites for bone tissue-engineering applications consisting of gellan gum hydrogels mineralized with calcium and magnesium phosphate phases by enzymatic means. J. Tissue Eng. Regener. Med. 2016, 10, 938-954. [CrossRef] [PubMed]

35. Kim, W.K.; Choi, J.H.; Shin, M.E.; Kim, J.W.; Kim, P.Y.; Kim, N.; Song, J.E.; Khang, G. Evaluation of cartilage regeneration of chondrocyte encapsulated gellan gum-based hyaluronic acid blended hydrogel. Int. J. Biol. Macromol. 2019, 141, 51-59. [CrossRef] [PubMed]

36. Kim, D.; Thangavelu, M.; Cheolui, S.; Kim, H.S.; Choi, M.J.; Song, J.E.; Khang, G. Effect of different concentration of demineralized bone powder with gellan gum porous scaffold for the application of bone tissue regeneration. Int. J. Biol. Macromol. 2019, 134, 749-758. [CrossRef] [PubMed]

37. Kim, H.S.; Kim, D.; Jeong, Y.W.; Choi, M.J.; Lee, G.W.; Thangavelu, M.; Song, J.E.; Khang, G. Engineering retinal pigment epithelial cells regeneration for transplantation in regenerative medicine using PEG/Gellan gum hydrogels. Int. J. Biol. Macromol. 2019, 130, 220-228. [CrossRef] [PubMed]

38. Shin, E.Y.; Park, J.H.; Shin, M.E.; Song, J.E.; Carlomagno, C.; Khang, G. Evaluation of Chondrogenic Differentiation Ability of Bone Marrow Mesenchymal Stem Cells in Silk Fibroin/Gellan Gum Hydrogels Using miR-30. Macromol. Res. 2019, 27, 369-376. [CrossRef]

39. Baek, J.S.; Carlomagno, C.; Muthukumar, T.; Kim, D.; Park, J.H.; Song, J.E.; Migliaresi, C.; Motta, A.; Reis, R.L.; Khang, G. Evaluation of Cartilage Regeneration in Gellan Gum/agar Blended Hydrogel with Improved Injectability. Macromol. Res. 2019, 27, 558-564. [CrossRef]

40. Jeon, H.Y.; Shin, E.Y.; Choi, J.H.; Song, J.E.; Reis, R.L.; Khang, G. Evaluation of Saponin Loaded Gellan Gum Hydrogel Scaffold for Cartilage Regeneration. Macromol. Res. 2018, 26, 724-729. [CrossRef]

41. Choi, I.; Kim, C.; Song, J.E.; Baek, J.; Jeon, S.H.; Jeon, H.; Lee, S.Y.; Khang, G. A Comprehensive Study on Cartilage Regeneration Using Gellan-gum/Chondroitin Sulfate Hybrid Hydrogels. Polymer Korea 2017, 41, 962-966. [CrossRef]

42. Jana, S.; Sen, K.K. Gellan gum/PVA Interpenetrating Network Micro-beads for Sustained Drug Delivery. Mater. Today-Proce. 2019, 11, 614-619. [CrossRef]

43. Yu, I.; Kaonis, S.; Chen, R. A Study on Degradation Behavior of 3D Printed Gellan Gum Scaffolds. Procedia CIRP 2017, 65, 78-83. [CrossRef]

44. Picone, C.S.F.; da Cunha, R.L. Interactions between milk proteins and gellan gum in acidified gels. Food Hydrocoll. 2010, 24, 502-511. [CrossRef]

45. Karthika, J.S.; Vishalakshi, B.; Naik, J. Gellan gum-graft-polyaniline-An electrical conducting biopolymer. Int. J. Biol. Macromol. 2016, 82, 61-67. [CrossRef] [PubMed]

46. Novac, O.; Lisa, G.; Profire, L.; Tuchilus, C.; Popa, M.I. Antibacterial quaternized gellan gum based particles for controlled release of ciprofloxacin with potential dermal applications. Mat. Sci. Eng. C-Mater. 2014, 35, 291-299. [CrossRef]

47. Kumar, S.; Kaur, P.; Bernela, M.; Rani, R.; Thakur, R. Ketoconazole encapsulated in chitosan-gellan gum nanocomplexes exhibits prolonged antifungal activity. Int. J. Biol. Macromol. 2016, 93, 988-994. [CrossRef]

48. Sarkar, D.; Nandi, G.; Changder, A.; Hudati, P.; Sarkar, S.; Ghosh, L.K. Sustained release gastroretentive tablet of metformin hydrochloride based on poly (acrylic acid)-grafted-gellan. Int. J. Biol. Macromol. 2017, 96, 137-148. [CrossRef]

49. Pacelli, S.; Paolicelli, P.; Moretti, G.; Petralito, S.; Di Giacomo, S.; Vitalone, A.; Casadei, M.A. Gellan gum methacrylate and laponite as an innovative nanocomposite hydrogel for biomedical applications. Eur. Polym. J. 2016, 77, 114-123. [CrossRef]

50. Kulkarni, R.V.; Mangond, B.S.; Mutalik, S.; Sa, B. Interpenetrating polymer network microcapsules of gellan gum and egg albumin entrapped with diltiazem-resin complex for controlled release application. Carbohydr. Polym. 2011, 83, 1001-1007. [CrossRef]

51. Oliveira, M.B.; Custodio, C.A.; Gasperini, L.; Reis, R.L.; Mano, J.F. Autonomous osteogenic differentiation of hASCs encapsulated in methacrylated gellan-gum hydrogels. Acta Biomater 2016, 41, 119-132. [CrossRef]

52. Coutinho, D.F.; Sant, S.V.; Shin, H.; Oliveira, J.T.; Gomes, M.E.; Neves, N.M.; Khademhosseini, A.; Reis, R.L. Modified Gellan Gum hydrogels with tunable physical and mechanical properties. Biomaterials 2010, 31, 7494-7502. [CrossRef] 
53. Mazzuca, C.; Micheli, L.; Carbone, M.; Basoli, F.; Cervelli, E.; Iannuccelli, S.; Sotgiu, S.; Palleschi, A. Gellan hydrogel as a powerful tool in paper cleaning process: A detailed study. J. Colloid Interface Sci. 2014, 416, 205-211. [CrossRef] [PubMed]

54. Dolan, L.C.; Matulka, R.A.; LeBeau, A.L.; Boulet, J.M. Two new nontoxic, non-pathogenic strains of Sphingomonas elodea for gellan gum production. Regul. Toxicol. Pharm. 2016, 78, 37-44. [CrossRef] [PubMed]

55. Matsukawa, S.; Tang, Z.; Watanabe, T. Hydrogen-bonding behavior of gellan in solution during structural change observed by 1 H NMR and circular dichroism methods. In Physical Chemistry and Industrial Application of Gellan Gum; Nishinari, K., Ed.; Springer: Berlin/Heidelberg, Germany, 1999; pp. 15-24.

56. Shin, H.; Olsen, B.D.; Khademhosseini, A. The mechanical properties and cytotoxicity of cell-laden double-network hydrogels based on photocrosslinkable gelatin and gellan gum biomacromolecules. Biomaterials 2012, 33, 3143-3152. [CrossRef] [PubMed]

57. Nichol, J.W.; Koshy, S.T.; Bae, H.; Hwang, C.M.; Yamanlar, S.; Khademhosseini, A. Cell-laden microengineered gelatin methacrylate hydrogels. Biomaterials 2010, 31, 5536-5544. [CrossRef]

58. Silva-Correia, J.; Oliveira, J.M.; Caridade, S.G.; Oliveira, J.T.; Sousa, R.A.; Mano, J.F.; Reis, R.L. Gellan gum-based hydrogels for intervertebral disc tissue-engineering applications. J. Tissue Eng. Regener. Med. 2011, 5, e97-e107. [CrossRef]

59. Ferris, C.J.; Stevens, L.R.; Gilmore, K.J.; Mume, E.; Greguric, I.; Kirchmajer, D.M.; Wallace, G.G.; in het Panhuis, M. Peptide modification of purified gellan gum. J. Mater. Chem. B 2015, 3, 1106-1115. [CrossRef]

60. Tang, Y.; Sun, J.; Fan, H.; Zhang, X. An improved complex gel of modified gellan gum and carboxymethyl chitosan for chondrocytes encapsulation. Carbohydr. Polym. 2012, 88, 46-53. [CrossRef]

61. Hahn, S.K.; Park, J.K.; Tomimatsu, T.; Shimoboji, T. Synthesis and degradation test of hyaluronic acid hydrogels. Int. J. Biol. Macromol. 2007, 40, 374-380. [CrossRef]

62. Oudshoorn, M.H.M.; Rissmann, R.; Bouwstra, J.A.; Hennink, W.E. Synthesis of methacrylated hyaluronic acid with tailored degree of substitution. Polymer 2007, 48, 1915-1920. [CrossRef]

63. Van Den Bulcke, A.I.; Bogdanov, B.; De Rooze, N.; Schacht, E.H.; Cornelissen, M.; Berghmans, H. Structural and rheological properties of methacrylamide modified gelatin hydrogels. Biomacromolecules 2000, 1, 31-38. [CrossRef]

64. Chou, A.I.; Nicoll, S.B. Characterization of photocrosslinked alginate hydrogels for nucleus pulposus cell encapsulation. J. Biomed. Mater. Res. 2009, 91, 187-194. [CrossRef] [PubMed]

65. Choi, J.H.; Choi, O.K.; Lee, J.; Noh, J.; Lee, S.; Park, A.; Rim, M.A.; Reis, R.L.; Khang, G. Evaluation of double network hydrogel of poloxamer-heparin/gellan gum for bone marrow stem cells delivery carrier. Colloids Surf. B-Biointer. 2019, 181, 879-889. [CrossRef] [PubMed]

66. George, A.; Shah, P.A.; Shrivastav, P.S. Guar gum: Versatile natural polymer for drug delivery applications. Eur. Polym. J. 2019, 112, 722-735. [CrossRef]

67. da Silva, L.P.; Cerqueira, M.T.; Sousa, R.A.; Reis, R.L.; Correlo, V.M.; Marques, A.P. Engineering cell-adhesive gellan gum spongy-like hydrogels for regenerative medicine purposes. Acta Biomater 2014, 10, 4787-4797. [CrossRef]

68. Miyamoto, K.; Tsuji, K.; Nakamura, T.; Tokita, M.; Komai, T. Preparation of carboxymethyl-gellan. Carbohydr. Polym. 1996, 30, 161-164. [CrossRef]

69. Du, H.; Hamilton, P.; Reilly, M.; Ravi, N. Injectable in situ physically and chemically crosslinkable gellan hydrogel. Macromol. Biosci. 2012, 12, 952-961. [CrossRef]

70. D’Arrigo, G.; Navarro, G.; Di Meo, C.; Matricardi, P.; Torchilin, V. Gellan gum nanohydrogel containing anti-inflammatory and anti-cancer drugs: A multi-drug delivery system for a combination therapy in cancer treatment. Eur. J. Pharm. Biopharem. 2014, 87, 208-216. [CrossRef]

71. Monica, R.P.R.; Mayuri, K.M. Multiparticulate Drug Delivery System for Gastrointestinal Tuberculosis. Int.J. Pharm. Sci. Drug Res. 2019, 11, 210-220.

72. Tripathi, G.K.; Singh, S.; Nath, G. Formulation and In-vitro Evaluation of pH-Sensitive Oil Entrapped Polymeric Blend Amoxicillin Beads for the Eradication of Helicobacter pylori. Iran. J. Pharm. Res. 2012, 11, 447-455.

73. Srinatha, A.; Pandit, J.K. Multi-unit floating alginate system: Effect of additives on ciprofloxacin release. Drug Deliv. 2008, 15, 471-476. [CrossRef] 
74. Milivojevic, M.; Pajic-Lijakovic, I.; Bugarski, B.; Nayak, A.K.; Hasnain, M.S. Chapter 6-Gellan gum in drug delivery applications. In Natural Polysaccharides in Drug Delivery and Biomedical Applications; Hasnain, M.S., Nayak, A.K., Eds.; Academic Press: Cambridge, MA, USA, 2019; pp. 145-186.

75. Dhar, S.; Mali, V.; Bodhankar, S.; Shiras, A.; Prasad, B.L.; Pokharkar, V. Biocompatible gellan gum-reduced gold nanoparticles: Cellular uptake and subacute oral toxicity studies. J. Appl. Toxic. 2011, 31, 411-420. [CrossRef] [PubMed]

76. Dhar, S.; Reddy, E.M.; Shiras, A.; Pokharkar, V.; Prasad, B.L. Natural gum reduced/stabilized gold nanoparticles for drug delivery formulations. Chemistry (Weinheim an der Bergstrasse, Germany) 2008, 14, 10244-10250. [CrossRef] [PubMed]

77. Dhar, S.; Murawala, P.; Shiras, A.; Pokharkar, V.; Prasad, B.L. Gellan gum capped silver nanoparticle dispersions and hydrogels: Cytotoxicity and in vitro diffusion studies. Nanoscale 2012, 4, 563-567. [CrossRef] [PubMed]

78. Vieira, S.; Vial, S.; Maia, F.R.; Carvalho, M.; Reis, R.L.; Granja, P.L.; Oliveira, J.M. Gellan gum-coated gold nanorods: An intracellular nanosystem for bone tissue engineering. RSC Adv. 2015, 5, 77996-78005. [CrossRef]

79. Fialho, A.M.; Moreira, L.M.; Granja, A.T.; Popescu, A.O.; Hoffmann, K.; Sa-Correia, I. Occurrence, production, and applications of gellan: Current state and perspectives. Appl. Microbiol. Biotechnol. 2008, 79, 889-900. [CrossRef]

80. Rozier, A.; Mazuel, C.; Grove, J.; Plazonnet, B. Gelrite ${ }^{\circledR}$ : A novel, ion-activated, in-situ gelling polymer for ophthalmic vehicles. Effect on bioavailability of timolol. Int. J. Pharm. 1989, 57, 163-168. [CrossRef]

81. Gal, A.; Nussinovitch, A. Hydrocolloid carriers with filler inclusion for diltiazem hydrochloride release. J. Pharm. Sci. 2007, 96, 168-178. [CrossRef]

82. Li, J.; Kamath, K.; Dwivedi, C. Gellan film as an implant for insulin delivery. J. Biomater. Appl. 2001, 15, 321-343. [CrossRef]

83. Jeon, S.H.; Lee, W.T.; Song, J.E.; Park, H.; Choi, I.N.; Kim, C.M.; Khang, G. Cartilage Regeneration Using Hesperidin-Containing Gellan Gum Scaffolds. Polym. Korea 2017, 41, 670-674. [CrossRef]

84. Bhalerao, H.; Koteshwara, K.B.; Chandran, S. Levofloxacin Hemihydrate In Situ Gelling Ophthalmic Solution: Formulation Optimization and In Vitro and In Vivo Evaluation. AAPS Pharm. Sci. Tech. 2019, 20, 272. [CrossRef]

85. Vashisth, P.; Raghuwanshi, N.; Srivastava, A.K.; Singh, H.; Nagar, H.; Pruthi, V. Ofloxacin loaded gellan/PVA nanofibers - Synthesis, characterization and evaluation of their gastroretentive/mucoadhesive drug delivery potential. Mater. Sci. Eng-C 2017, 71, 611-619. [CrossRef] [PubMed]

86. Vashisth, P.; Nikhil, K.; Roy, P.; Pruthi, P.A.; Singh, R.P.; Pruthi, V. A novel gellan-PVA nanofibrous scaffold for skin tissue regeneration: Fabrication and characterization. Carbohydr. Polym. 2016, 136, 851-859. [CrossRef] [PubMed]

87. Rostami, M.; Ghorbani, M.; Aman mohammadi, M.; Delavar, M.; Tabibiazar, M.; Ramezani, S. Development of resveratrol loaded chitosan-gellan nanofiber as a novel gastrointestinal delivery system. Int. J. Biol. Macromol. 2019, 135, 698-705. [CrossRef] [PubMed]

88. Mehnath, S.; Ayisha Sithika, M.A.; Arjama, M.; Rajan, M.; Amarnath Praphakar, R.; Jeyaraj, M. Sericin-chitosan doped maleate gellan gum nanocomposites for effective cell damage in Mycobacterium tuberculosis. Int. J. Biol. Macromol. 2019, 122, 174-184. [CrossRef] [PubMed]

89. Verma, A.; Tiwari, A.; Panda, P.K.; Saraf, S.; Jain, A.; Jain, S.K. Chapter 8-Locust bean gum in drug delivery application. In Natural Polysaccharides in Drug Delivery and Biomedical Applications; Hasnain, M.S., Nayak, A.K., Eds.; Academic Press: Cambridge, MA, USA, 2019; pp. 203-222.

90. Izawa, H.; Nishino, S.; Maeda, H.; Morita, K.; Ifuku, S.; Morimoto, M.; Saimoto, H.; Kadokawa, J.-i. Mineralization of hydroxyapatite upon a unique xanthan gum hydrogel by an alternate soaking process. Carbohydr. Polym. 2014, 102, 846-851. [CrossRef]

91. Kuo, S.M.; Chang, S.J.; Wang, H.Y.; Tang, S.C.; Yang, S.W. Evaluation of the ability of xanthan gum/gellan gum/hyaluronan hydrogel membranes to prevent the adhesion of postrepaired tendons. Carbohydr. Polym. 2014, 114, 230-237. [CrossRef]

92. Oliveira Cardoso, V.M.; Stringhetti Ferreira Cury, B.; Evangelista, R.C.; Daflon Gremiao, M.P. Development and characterization of cross-linked gellan gum and retrograded starch blend hydrogels for drug delivery applications. J. Mech Behav Biomed. Mater. 2017, 65, 317-333. [CrossRef] 
93. Fernandez-Ferreiro, A.; Silva-Rodriguez, J.; Otero-Espinar, F.J.; Gonzalez-Barcia, M.; Lamas, M.J.; Ruibal, A.; Luaces-Rodriguez, A.; Vieites-Prado, A.; Lema, I.; Herranz, M.; et al. In vivo eye surface residence determination by high-resolution scintigraphy of a novel ion-sensitive hydrogel based on gellan gum and kappa-carrageenan. Eur. J. Pharm. Biopharem. 2017, 114, 317-323. [CrossRef]

94. Emeje, M.O.; Franklin-Ude, P.I.; Ofoefule, S.I. Evaluation of the fluid uptake kinetics and drug release from gellan gum tablets containing metronidazole. Int. J. Biol. Macromol. 2010, 47, 158-163. [CrossRef]

95. Qin, F.; Man, J.; Cai, C.; Xu, B.; Gu, M.; Zhu, L.; Shi, Y.-C.; Liu, Q.; Wei, C. Physicochemical properties of high-amylose rice starches during kernel development. Carbohydr. Polym. 2012, 88, 690-698. [CrossRef]

96. Rajinikanth, P.S.; Mishra, B. Preparation and in vitro characterization of gellan based floating beads of acetohydroxamic acid for eradication of H. pylori. Acta Pharm. (Zagreb, Croatia) 2007, 57, 413-427. [CrossRef] [PubMed]

97. Schiavi, A.; Cuccaro, R.; Troia, A. Strain-rate and temperature dependent material properties of Agar and Gellan Gum used in biomedical applications. J. Mech Behav Biomed. Mater. 2016, 53, 119-130. [CrossRef] [PubMed]

98. Amin, K.A.M.; Panhuis, M.i.h. Polyelectrolyte complex materials from chitosan and gellan gum. Carbohydr. Polym. 2011, 86, 352-358. [CrossRef]

99. Ahuja, M.; Yadav, M.; Kumar, S. Application of response surface methodology to formulation of ionotropically gelled gum cordia/gellan beads. Carbohydr. Polym. 2010, 80, 161-167. [CrossRef]

100. Ismail, N.A.; Amin, K.A.M.; Majid, F.A.A.; Razali, M.H. Gellan gum incorporating titanium dioxide nanoparticles biofilm as wound dressing: Physicochemical, mechanical, antibacterial properties and wound healing studies. Mat. Sci. Eng. C-Mater. 2019, 103, 109770. [CrossRef] [PubMed]

101. Stevens, L.R.; Gilmore, K.J.; Wallace, G.G.; in het Panhuis, M. Tissue engineering with gellan gum. Biomater. Sci. 2016, 4, 1276-1290. [CrossRef]

102. Cerqueira, M.T.; da Silva, L.P.; Santos, T.C.; Pirraco, R.P.; Correlo, V.M.; Reis, R.L.; Marques, A.P. Gellan gum-hyaluronic acid spongy-like hydrogels and cells from adipose tissue synergize promoting neoskin vascularization. ACS Appl Mater. Interfaces 2014, 6, 19668-19679. [CrossRef]

103. Kirchmajer, D.M.; Steinhoff, B.; Warren, H.; Clark, R.; in het Panhuis, M. Enhanced gelation properties of purified gellan gum. Carbohydr Res. 2014, 388, 125-129. [CrossRef]

104. Pina, S.; Oliveira, J.M.; Reis, R.L. Natural-based nanocomposites for bone tissue engineering and regenerative medicine: A review. Advanced Mater. (Deerfield Beach, Fla.) 2015, 27, 1143-1169. [CrossRef]

105. Douglas, T.E.; Wlodarczyk, M.; Pamula, E.; Declercq, H.A.; de Mulder, E.L.; Bucko, M.M.; Balcaen, L.; Vanhaecke, F.; Cornelissen, R.; Dubruel, P.; et al. Enzymatic mineralization of gellan gum hydrogel for bone tissue-engineering applications and its enhancement by polydopamine. J. Tissue Eng. Regener. Med. 2014, 8, 906-918. [CrossRef]

106. Khang, G.; Lee, S.K.; Kim, H.N.; Silva-Correia, J.; Gomes, M.E.; Viegas, C.A.; Dias, I.R.; Oliveira, J.M.; Reis, R.L. Biological evaluation of intervertebral disc cells in different formulations of gellan gum-based hydrogels. J. Tissue Eng. Regener. Med. 2015, 9, 265-275. [CrossRef] [PubMed]

107. Shin, H.; Olsen, B.D.; Khademhosseini, A. Gellan gum microgel-reinforced cell-laden gelatin hydrogels. J. Mater. Chem. B 2014, 2, 2508-2516. [CrossRef] [PubMed]

108. Xu, Z.; Li, Z.; Jiang, S.; Bratlie, K.M. Chemically Modified Gellan Gum Hydrogels with Tunable Properties for Use as Tissue Engineering Scaffolds. ACS Omega 2018, 3, 6998-7007. [CrossRef] [PubMed]

109. Vilela, C.A.; Correia, C.; da Silva Morais, A.; Santos, T.C.; Gertrudes, A.C.; Moreira, E.S.; Frias, A.M.; Learmonth, D.A.; Oliveira, P.; Oliveira, J.M.; et al. In vitro and in vivo performance of methacrylated gellan gum hydrogel formulations for cartilage repair. J. Biomed. Mater. Res. Part A 2018, 106, 1987-1996. [CrossRef]

110. Lee, M.W.; Tsai, H.F.; Wen, S.M.; Huang, C.H. Photocrosslinkable gellan gum film as an anti-adhesion barrier. Carbohydr. Polym. 2012, 90, 1132-1138. [CrossRef]

111. Visser, J.; Peters, B.; Burger, T.J.; Boomstra, J.; Dhert, W.J.; Melchels, F.P.; Malda, J. Biofabrication of multi-material anatomically shaped tissue constructs. Biofabrication 2013, 5, 035007. [CrossRef]

112. Adrover, A.; Paolicelli, P.; Petralito, S.; Di Muzio, L.; Trilli, J.; Cesa, S.; Tho, I.; Casadei, M.A. Gellan Gum/Laponite Beads for the Modified Release of Drugs: Experimental and Modeling Study of Gastrointestinal Release. Pharmaceutics 2019, 11, 187. [CrossRef]

113. Zhao, X.; Wang, Z. A pH-sensitive microemulsion-filled gellan gum hydrogel encapsulated apigenin: Characterization and in vitro release kinetics. Colloids Surf. B Biointerfaces 2019, 178, 245-252. [CrossRef] 
114. Gering, C.; Koivisto, J.T.; Parraga, J.; Leppiniemi, J.; Vuornos, K.; Hytonen, V.P.; Miettinen, S.; Kellomaki, M. Design of modular gellan gum hydrogel functionalized with avidin and biotinylated adhesive ligands for cell culture applications. PloS ONE 2019, 14, e0221931. [CrossRef]

115. Bastos, A.R.; da Silva, L.P.; Maia, F.R.; Pina, S.; Rodrigues, T.; Sousa, F.; Oliveira, J.M.; Cornish, J.; Correlo, V.M.; Reis, R.L. Lactoferrin-Hydroxyapatite Containing Spongy-Like Hydrogels for Bone Tissue Engineering. Materials (Basel) 2019, 12, 2074. [CrossRef]

116. D'Arrigo, G.; Di Meo, C.; Gaucci, E.; Chichiarelli, S.; Coviello, T.; Capitani, D.; Alhaique, F.; Matricardi, P. Self-assembled gellan-based nanohydrogels as a tool for prednisolone delivery. Soft Matter 2012, 8, 11557-11564. [CrossRef]

117. Swain, G.P.; Patel, S.; Gandhi, J.; Shah, P. Development of Moxifloxacin Hydrochloride loaded in-situ gel for the treatment of periodontitis: In-vitro drug release study and antibacterial activity. J. Oral Biol. Craniofac. Res. 2019, 9, 190-200. [CrossRef] [PubMed]

118. Aadil, K.R.; Nathani, A.; Sharma, C.S.; Lenka, N.; Gupta, P. Investigation of poly(vinyl) alcohol-gellan gum based nanofiber as scaffolds for tissue engineering applications. J. Drug Deliv. Sci. Technol. 2019, 54, 101276. [CrossRef]

119. Barbosa, E.J.; Ferraz, H.G. Gellan gum and polyvinylpyrrolidone (PVP) as binding agents in extrusion/spheronization pellet formulations. Acta Pharm. (Zagreb, Croatia) 2019, 69, 99-109. [CrossRef]

120. Wang, C.; Gong, Y.; Lin, Y.; Shen, J.; Wang, D.A. A novel gellan gel-based microcarrier for anchorage-dependent cell delivery. Acta Biomater 2008, 4, 1226-1234. [CrossRef] [PubMed]

121. Rada, T.; Carvalho, P.P.; Santos, T.C.; Castro, A.G.; Reis, R.L.; Gomes, M.E. Chondrogenic potential of two hASCs subpopulations loaded onto gellan gum hydrogel evaluated in a nude mice model. Curr. Stem. Cell Res. Ther. 2013, 8, 357-364. [CrossRef]

122. Ahearne, M.; Kelly, D.J. A comparison of fibrin, agarose and gellan gum hydrogels as carriers of stem cells and growth factor delivery microspheres for cartilage regeneration. Biomed. Mater. (Bristol, England) 2013, 8, 035004. [CrossRef]

123. Duarte Pereira, H.M.; Silva-Correia, J.; Yan, L.-P.; Caridade, S.G.; Frias, A.M.; Oliveira, A.L.; Mano, J.F.; Oliveira, J.M.; Espregueira-Mendes, J.; dos Reis, R.L.G.; et al. Silk-Fibroin/Methacrylated Gellan Gum Hydrogel As An Novel Scaffold For Application In Meniscus Cell-Based Tissue Engineering. Arthroscopy 2013, 29, e53-e55. [CrossRef]

124. Ku, K.C.; Lee, M.W.; Kuo, S.M.; Yao, C.H.; Chang, S.J. Preparation and evaluation of collagen I/ gellan gum/beta-TCP microspheres as bone graft substitute materials. In Proceedings of the 35th Annual International Conference of the IEEE Engineering in Medicine and Biology Society, Osaka, Japan, 3-7 July 2013; pp. 6667-6670.

125. Silva-Correia, J.; Gloria, A.; Oliveira, M.B.; Mano, J.F.; Oliveira, J.M.; Ambrosio, L.; Reis, R.L. Rheological and mechanical properties of acellular and cell-laden methacrylated gellan gum hydrogels. J. Biomed. Mater. Res. 2013, 101, 3438-3446. [CrossRef]

126. Mouser, V.H.; Melchels, F.P.; Visser, J.; Dhert, W.J.; Gawlitta, D.; Malda, J. Yield stress determines bioprintability of hydrogels based on gelatin-methacryloyl and gellan gum for cartilage bioprinting. Biofabrication 2016, 8 , 035003. [CrossRef]

127. Melchels, F.P.W.; Dhert, W.J.A.; Hutmacher, D.W.; Malda, J. Development and characterisation of a new bioink for additive tissue manufacturing. J. Mater. Chem. B 2014, 2, 2282-2289. [CrossRef]

128. Vijan, V.; Kaity, S.; Biswas, S.; Isaac, J.; Ghosh, A. Microwave assisted synthesis and characterization of acrylamide grafted gellan, application in drug delivery. Carbohydr. Polym. 2012, 90, 496-506. [CrossRef] [PubMed]

129. Osmalek, T.Z.; Froelich, A.; Sobol, M.; Milanowski, B.; Skotnicki, M.; Kunstman, P.; Szybowicz, M. Gellan gum macrobeads loaded with naproxen: The impact of various naturally derived polymers on $\mathrm{pH}$-dependent behavior. J. Biomater. Appl. 2018, 33, 140-155. [CrossRef] [PubMed]

130. Agnihotri, S.A.; Aminabhavi, T.M. Development of novel interpenetrating network gellan gum-poly(vinyl alcohol) hydrogel microspheres for the controlled release of carvedilol. Drug Develop. Industr. Pharm. 2005, 31, 491-503. [CrossRef]

131. Wu, R.L.; Zhao, C.S.; Xie, J.W.; Yi, S.L.; Song, H.T.; He, Z.G. Preparation of in situ gel systems for the oral delivery of ibuprofen and its pharmacokinetics study in beagle dogs. Acta pharmac. Sinica 2008, 43, 956-962. 
132. Bhattacharya, S.S.; Banerjee, S.; Chowdhury, P.; Ghosh, A.; Hegde, R.R.; Mondal, R. Tranexamic acid loaded gellan gum-based polymeric microbeads for controlled release: In vitro and in vivo assessment. Colloids Surf. B Biointerfaces 2013, 112, 483-491. [CrossRef]

133. Cencetti, C.; Bellini, D.; Pavesio, A.; Senigaglia, D.; Passariello, C.; Virga, A.; Matricardi, P. Preparation and characterization of antimicrobial wound dressings based on silver, gellan, PVA and borax. Carbohydr. Polym. 2012, 90, 1362-1370. [CrossRef]

134. Shukla, R.; Kashaw, S.K.; Jain, A.P.; Lodhi, S. Fabrication of Apigenin loaded gellan gum-chitosan hydrogels (GGCH-HGs) for effective diabetic wound healing. Int. J. Biol. Macromol. 2016, 91, 1110-1119. [CrossRef]

135. Tsai, W.; Tsai, H.; Wong, Y.; Hong, J.; Chang, S.; Lee, M. Preparation and characterization of gellan gum/glucosamine/clioquinol film as oral cancer treatment patch. Mat. Sci. Eng. C-Mater. 2018, 82, 317-322. [CrossRef]

136. Song, J.E.; Song, Y.S.; Jeon, S.H.; Choi, I.N.; Kim, C.M.; Khang, G. Evaluation of Gelatin and Gellan Gum Blended Hydrogel for Cartilage Regeneration. Polymer Korea 2017, 41, 619-623. [CrossRef]

137. Song, J.E.; Lee, S.E.; Cha, S.R.; Jang, N.K.; Tripathy, N.; Reis, R.L.; Khang, G. Inflammatory response study of gellan gum impregnated duck's feet derived collagen sponges. J. Biomater. Sci. Polym. Ed. 2016, 27, 1495-1506. [CrossRef] [PubMed]

138. Vashisth, P.; Pruthi, P.A.; Singh, R.P.; Pruthi, V. Process optimization for fabrication of gellan based electrospun nanofibers. Carbohydr. Polym. 2014, 109, 16-21. [CrossRef] [PubMed]

139. Bera, H.; Ang, S.R.; Chiong, S.W.; Chan, C.H.; Abbasi, Y.F.; Law, L.P.; Chatterjee, B.; Venugopal, V. Core-shell structured pullulan based nanocomposites as erlotinib delivery shuttles. Int. J. Polym. Mater. Polym. Biomater. 2019, 1-12. [CrossRef]

140. Tatke, A.; Dudhipala, N.; Janga, K.Y.; Balguri, S.P.; Avula, B.; Jablonski, M.M.; Majumdar, S. In Situ Gel of Triamcinolone Acetonide-Loaded Solid Lipid Nanoparticles for Improved Topical Ocular Delivery: Tear Kinetics and Ocular Disposition Studies. Nanomaterials (Basel, Switzerland) 2018, 9, 33. [CrossRef]

141. Arjama, M.; Mehnath, S.; Rajan, M.; Jeyaraj, M. Sericin/RBA embedded gellan gum based smart nanosystem for $\mathrm{pH}$ responsive drug delivery. Int. J. Biol. Macromol. 2018, 120, 1561-1571. [CrossRef]

142. Janga, K.Y.; Tatke, A.; Balguri, S.P.; Lamichanne, S.P.; Ibrahim, M.M.; Maria, D.N.; Jablonski, M.M.; Majumdar, S. Ion-sensitive in situ hydrogels of natamycin bilosomes for enhanced and prolonged ocular pharmacotherapy: In vitro permeability, cytotoxicity and in vivo evaluation. Artif. Cells Nanomed. Biotechnol. 2018, 46, 1039-1050. [CrossRef]

143. Dhanka, M.; Shetty, C.; Srivastava, R. Methotrexate loaded gellan gum microparticles for drug delivery. Int. J. Biol. Macromol. 2018, 110, 346-356. [CrossRef]

144. Sun, J.; Zhou, Z. A novel ocular delivery of brinzolamide based on gellan gum: In vitro and in vivo evaluation. Drug Des. Devel. Ther. 2018, 12,383-389. [CrossRef]

145. Silva-Correia, J.; Miranda-Goncalves, V.; Salgado, A.J.; Sousa, N.; Oliveira, J.M.; Reis, R.M.; Reis, R.L. Angiogenic potential of gellan-gum-based hydrogels for application in nucleus pulposus regeneration: In vivo study. Tissue Eng. Part. A 2012, 18, 1203-1212. [CrossRef]

146. Ayala, R.; Zhang, C.; Yang, D.; Hwang, Y.; Aung, A.; Shroff, S.S.; Arce, F.T.; Lal, R.; Arya, G.; Varghese, S. Engineering the cell-material interface for controlling stem cell adhesion, migration, and differentiation. Biomaterials 2011, 32, 3700-3711. [CrossRef]

147. Annabi, N.; Nichol, J.W.; Zhong, X.; Ji, C.; Koshy, S.; Khademhosseini, A.; Dehghani, F. Controlling the porosity and microarchitecture of hydrogels for tissue engineering. Tissue Eng. Part. B Rev. 2010, 16, 371-383. [CrossRef] [PubMed]

148. Frey, M.T.; Wang, Y.L. A photo-modulatable material for probing cellular responses to substrate rigidity. Soft Matter 2009, 5, 1918-1924. [CrossRef] [PubMed]

149. Hauswirth, W.W.; Aleman, T.S.; Kaushal, S.; Cideciyan, A.V.; Schwartz, S.B.; Wang, L.; Conlon, T.J.; Boye, S.L.; Flotte, T.R.; Byrne, B.J.; et al. Treatment of leber congenital amaurosis due to RPE65 mutations by ocular subretinal injection of adeno-associated virus gene vector: Short-term results of a phase I trial. Hum. Gene Ther. 2008, 19, 979-990. [CrossRef] [PubMed] 
150. Liu, T.; Jenwitheesuk, E.; Teller, D.C.; Samudrala, R. Structural insights into the cellular retinaldehyde-binding protein (CRALBP). Proteins 2005, 61, 412-422. [CrossRef]

151. Amirpour, N.; Karamali, F.; Rabiee, F.; Rezaei, L.; Esfandiari, E.; Razavi, S.; Dehghani, A.; Razmju, H.; Nasr-Esfahani, M.H.; Baharvand, H. Differentiation of human embryonic stem cell-derived retinal progenitors into retinal cells by Sonic hedgehog and/or retinal pigmented epithelium and transplantation into the subretinal space of sodium iodate-injected rabbits. Stem Cells Develop. 2012, 21, 42-53. [CrossRef]

(c) (1)

(C) 2019 by the authors. Licensee MDPI, Basel, Switzerland. This article is an open access article distributed under the terms and conditions of the Creative Commons Attribution (CC BY) license (http://creativecommons.org/licenses/by/4.0/). 